Review

\title{
Field Phenotyping and Long-Term Platforms to Characterise How Crop Genotypes Interact with Soil Processes and the Environment
}

\author{
Timothy S. George ${ }^{1}{ }^{*}$, Cathy Hawes ${ }^{1}$, Adrian C. Newton ${ }^{1}$, Blair M. McKenzie ${ }^{1}$,
} Paul D. Hallett ${ }^{2}$ and Tracy A. Valentine ${ }^{1}$

1 The James Hutton Institute, Invergowrie, Dundee DD2 5DA, UK;

E-Mails: cathy.hawes@hutton.ac.uk (C.H.); adrian.newton@hutton.ac.uk (A.C.N.);

blair.mckenzie@hutton.ac.uk (B.M.M.); tracy.valentine@hutton.ac.uk (T.A.V.)

2 Institute of Biological and Environmental Sciences, University of Aberdeen, Aberdeen AB24 3UU, UK; E-Mail: paul.hallett@abdn.ac.uk

* Author to whom correspondence should be addressed; E-Mail: tim.george@hutton.ac.uk; Tel.: +44-1382-568700; Fax: +44-844-9285429.

Received: 28 February 2014; in revised form: 3 May 2014 / Accepted: 12 May 2014 /

Published: 22 May 2014

\begin{abstract}
Unsustainable agronomic practices and environmental change necessitate a revolution in agricultural production to ensure food security. A new generation of crops that yield more with fewer inputs and are adapted to more variable environments is needed. However, major changes in breeding programmes may be required to achieve this goal. By using the genetic variation in crop yield in specific target environments that vary in soil type, soil management, nutrient inputs and environmental stresses, robust traits suited to specific conditions can be identified. It is here that long-term experimental platforms and field phenotyping have an important role to play. In this review, we will provide information about some of the field-based platforms available and the cutting edge phenotyping systems at our disposal. We will also identify gaps in our field phenotyping resources that should be filled. We will go on to review the challenges in producing crop ideotypes for the dominant management systems for which we need sustainable solutions, and we discuss the potential impact of three-way interactions between genetics, environment and management. Finally, we will discuss the role that modelling can play in allowing us to fast-track some of these processes to allow us to make rapid gains in agricultural sustainability.
\end{abstract}


Keywords: agronomy; field phenotyping; genetics; long-term platforms; organic production; pest and disease resistance; polyculture; reduced inputs; reduced tillage; roots

\section{Introduction}

With increasing world population, diminishing resources, unsustainable agronomic practices and environmental change there is an urgent need to change agricultural production to deliver long-term food security. This change must focus on crops that tolerate and that are productive in low-input and low-fertility environments, with gains needed across a range of crops [1]. This new generation of crops adapted to low/reduced input systems needs to be sustainable, global and at worst benign, but preferably restorative to the environment all of which is termed an "evergreen revolution" [2]. The key to breeding such crops will be the utilisation of the genetic variation in yield, identified in specific target environments and an understanding of how this yield variation interacts with management, the environment and a range of yield-decreasing stresses. Of the traits responsible for yield, variation in traits associated with roots has received the least research interest, despite a perception that roots contain the greatest untapped potential to deliver future sustainable crops [1,3-5]. Testing potentially beneficial genotypes in realistic field environments is critical to translate a genetic understanding of traits into sustainable production in the real world.

Such research can draw on the large collection of genetic resources and information on model plants and crops that have been assembled in recent years [6-9]. Ever increasing amounts of genetic sequence information and understanding of single nucleotide polymorphisms (SNPs) are available for the predominant cereals including wheat, rice, maize and barley. Further developments in rapid sequencing and methods to assess sequence polymorphisms plus the decrease in assay costs means that detailed genotypic data can be rapidly and efficiently generated for most populations of favoured species and can also be easy and logically extended to "orphan crops" or those that have had little study of their genetics, e.g., horticultural and tree crops; subsistence crops (cassava, millet, beans) and rare crops [10]. However, while rapid progress has been made in genetics and progress has been made in linking these polymorphisms to some important plant traits [11], we have now reached a "phenotyping bottleneck" where the ability to screen potentially important traits, particularly those manifest below ground, in realistic, variable environments limits our ability to translate the underpinning genetics to actual gains in sustainability. Recent developments in imaging, data handling and remote sensing hold particular promise for high throughput screening of plant structural, developmental or physiological characters. For example 3D imaging and laser scanning can provide information on plant structure [12], thermal imaging provides rapid diagnosis of plant responses to transpirational rate including water, temperature and osmostic stress, and hyperspectral sensing can provide information on biochemical and physiological responses of plants to pathogens and disease $[13,14]$. It is important that such data are gathered in appropriate field environments where the ultimate target is to enhance crop production by sustainable improvements that can be realized in agricultural situations.

One limitation in modern agriculture given insufficient attention by researchers is soil properties. Soil properties restrict crop production worldwide [1,15-17]. It is estimated that the majority of agricultural soils are either acidic [18,19], alkaline or calcareous [20], and saline or sodic [21,22]. 
These soils are compromised not only by high phytoavailability of toxic mineral elements, but also by limited phytoavailability of essential mineral elements $[16,17,23]$. The phytoavailabilities of nitrogen $(\mathrm{N})$, phosphorus $(\mathrm{P})$ and potassium $(\mathrm{K})$ limit crop production in most agricultural soils [1,24-26]. In addition, many of these soils will suffer from water availability related stresses including restricted root growth through mechanical impedance in drying soils [27], limited porosity [28,29], drought [30] and waterlogging [31]. The way that soils are managed has also changed dramatically in recent years, with over 110 Mha now cultivated with conservation tillage practices that disturb a shallower depth of soil [32]. An extreme shift is the adoption of zero tillage, which is now practised on over $20 \%$ of USA, almost half of Argentinian agricultural land and by $84 \%$ of Australian grain growers [33,34]. Conservation tillage creates a different environment for root development than deeper ploughing, with root elongation sometimes impeded by shallower plough pans [29]. Different root traits are required in these soils, but most modern breeding programmes still use soils cultivated to greater depths $(>15 \mathrm{~cm})[35,36]$. Add to this the fact that these crops are further challenged by pests and diseases, and the complexity of the limitations facing crop growth in the field becomes evident. Any attempt to field-phenotype potential future crop varieties needs to take into account how these limitations interact in space and time in the field.

A network of field-based experimental platforms that use modern agricultural practices and also trial future scenarios such as reduced fertiliser rates, integrated pest management and innovative soil management techniques, is required in order to translate the research money spent on genetic and genomic understanding of crop traits into gains in sustainable crop production in the field. Many such platforms are emerging internationally, but they tend to be dominated by single discipline research in agronomy, ecology or soil science, with only a handful used to study genetic $\times$ environment $(\mathrm{G} \times \mathrm{E})$ interactions in the search for more sustainable crops. A large bottleneck is the vast expense required in spatial and temporal sampling of genotypes in multiple environments, although recent advances in crop phenotyping technology are beginning to overcome this limitation [37], albeit with many approaches still limited to laboratory [38] or glasshouse studies [39]. The rapid assessment of root traits across genotypes in the field is still not possible and relies on manual excavation, hence the limited research in this area.

In this review we provide information about some of the field based platforms available and the cutting edge technology phenotyping systems at our disposal. We also identify gaps in our field phenotyping resources that should be filled. We review the challenges in designing and producing crop ideotypes for the predominant management systems and the sustainable solutions that are needed. We also discuss the potential impact of genetics-by-environment-by-management $(\mathrm{G} \times \mathrm{E} \times \mathrm{M})$ interactions. Finally, we will discuss the role modelling can play in allowing us to fast-track some of these processes to allow us to make rapid gains in agricultural sustainability. 


\section{Field Based Assessment of Impacts of Management and Environment on Crop Production}

\subsection{Long-Term Platforms}

Achieving sustainable agricultural production requires an understanding of biogeochemical cycles, environmental fluxes, the relation between biodiversity and system function with respect to the provision of regulating services, and abiotic and biotic stresses experienced by the crop. However, the response of these processes to changes in land management is often slow and requires long timescales for their impact to be properly assessed [40]. For instance, although changes in soil management can have immediate impact, they can also change gradually over time, and subsoil impacts $(55-60 \mathrm{~cm})$ may not be noticeable for 7 years [41]. In temperate climates it may take $>100$ years for a new equilibrium to be reached following major changes in land use or management [42], although data from the Rothamsted Broadbalk Classic Experiment indicates that soil organic carbon (SOC) can reach $50 \%$ of its final value in 25 years [43]. Similarly, Hofmann, et al. [44], using data from two long-term experiments (Cadriano, Italy, established in 1971 and the Askov Continuous Maize Experiment, Denmark, established in 1988) showed that lignin degradation in arable soils was slow, reaching $50 \%-60 \%$ of the initial total after 35 years.

Long-term experiments (LTEs) are therefore essential for research into the impact of management on environmental and biological processes, particularly where consistent long-term records are kept and soil and plant material is properly archived $[45,46]$. There are currently around 600 LTEs of more than 20 years duration worldwide [17,47] with a proportion of these established over 100 years ago. The distribution of LTEs relating specifically to arable systems (generally fertiliser, tillage and/or rotational trials) is shown in Figure 1, the most important of these include: the Rothamsted Classic Experiments (Broadbalk, Park Grass), UK 1843; Grignon, France 1875; Halle (Eternal Rye), Germany 1878; Askov (Fertilisation Experiment and The Straw Experiment), Denmark 1894; Bad Lauchstadt (Static Fertilisation Experiment), Germany 1902; Samaru (DNPK soil fertility experiment), Nigeria 1950; University of Illinois (Morrow plots), Illinois 1876. These "classic" LTEs tend to suffer some disadvantages in terms of experimental design, particularly limited replication, few treatment intensities, poor randomisation and changes in treatment over the course of the experiment. However, these problems are compensated by their long duration, providing time series data from which long term trends can be assessed.

LTEs with durations in excess of 20 years and consistently applied treatments often have well-established gradients in system properties. For example, fertility and $\mathrm{pH}$ gradients can be found at the LTE on liming and P-fertilisation established in St Jyndevad, Denmark in 1942, and the Hoosfield Acid Strip, Rothamsted, established in 1852. These established conditions provide ready-made field experiment platforms to study the effects on a wide range of different system properties. Provided good records are kept, archived data from established LTEs also represent a "platform" for research, providing long-term datasets for analysis of environmental fluxes and long-term trends in system responses to environmental change [48]. A number of databases of LTEs have been set-up to facilitate their use for new research including meta-analyses and modelling SOMNET (110 European LTEs on changes in soil organic matter [49]), Duke University Database [50], and the Inventory of 38 Nordic Long-term Agricultural Experiments [51]. 
Figure 1. Global distribution of long-term experiments in arable ecosystems, categorised by duration: red established for $>100$ years; green, 50-100 years; blue, 20-49 years; pink, <20 years. Data sourced from the Duke University long term data archive ([50], Duke University, Durham, NC, USA), excluding non-arable sites and those with no location information.

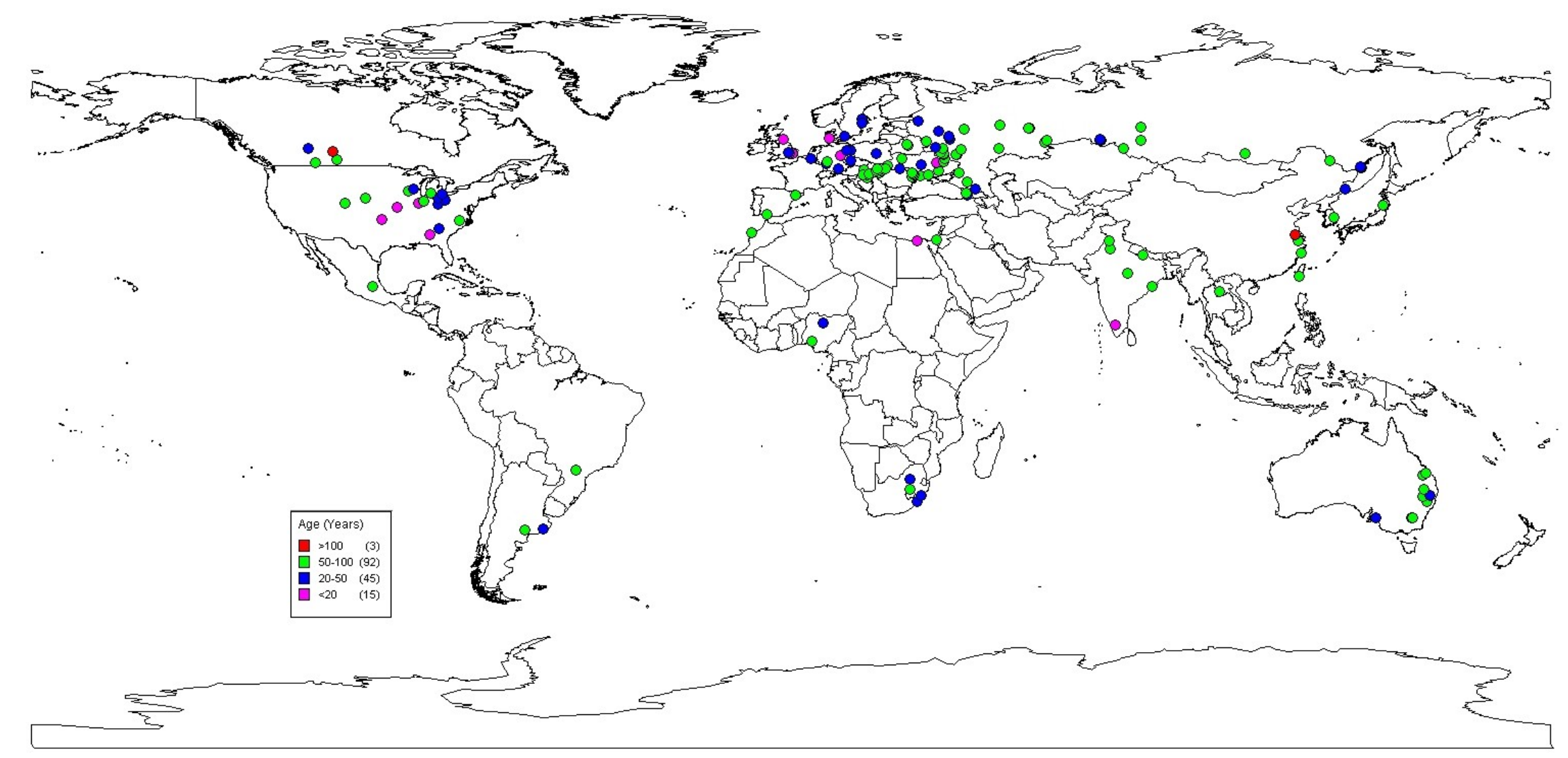


One of the main uses of these databases has been modelling carbon dynamics [52-56]. Data to validate and parameterise carbon dynamics models have been taken from a wide range of LTEs to estimate trends in soil carbon stocks. Key examples include the Askov Straw Experiment, Denmark established 1981, Rotthalmunster in South Bavaria, Germany established 1979, and "Eternal Rye" in Halle, Germany established 1878 with continuous maize included in 1961, the Morrow plots with continuous maize since 1876 and soil carbon data from 1904, Ultuna SOM stabilisation and turnover, Sweden [57], the DOK long-term trial comparing conventional, organic and biodynamic farming systems in Switzerland, established in 1978 [57], and the Pilmore Soil Disturbance Experiment, Dundee, UK established 2002 to assess cultivation effects on genotype performance, soil carbon and biophysics [58]. In these LTEs, the effects of management on SOC balances are integrated over decades [59], for example, data from a subset of 45 LTEs in Northern Europe was used to quantify influence of initial C stocks on soil C balances. Meta-analyses of LTE data should be performed with caution since there are many different sources of error and issues with comparability across LTEs, but on average, results are more realistic than data from short-term single site experiments.

LTEs have also been used to inform policy, generating estimates that would otherwise be impossible to obtain [60], for example, the Danish debate on measures and legislation regarding a prescribed $10 \%$ decrease in nitrogen fertiliser rates were based on Nordic long term fertiliser and soil nutrient experiments [40]. Datasets were collated from the Askov Animal Manure and Mineral Fertiliser Experiment (established in 1894) to test the effect of different levels of fertiliser on yield in a four-course rotation of winter cereals, row crops, spring cereals and grass/legumes), and from Moystad, South East Norway where the effect of mineral fertiliser and animal manure on soil structure, crop yields, economic returns and health have been compared since 1922 [61].

Mineral fertilisers may have a residual effect beyond the year of application, which may be minor in any one year, but have the potential to accumulate over longer times. Key LTEs that focus on rates and types of fertiliser and plant nutrition include [61], CIRAA in Central Italy which was established in 1991 to study the effect of tillage and $\mathrm{N}$ fertiliser management on continuous maize yield [62]; Akureyri and Samsstaoir, established in 1945 and Skriouklaustur, established in 1954 in Iceland to study the long term effect of different fertilisers on soil nutrients; 22 separate sites in Finland measured between 1977-1994 to look at P and K effects on yield [63,64], CRUCIAL which was established in 2002 to assess long-term effects of urban sourced fertiliser on soil fertility and the accumulation of heavy metals on soil ecological function [65]. These LTEs provide estimates of longer term effects and allow evaluation of soil organic $\mathrm{N}$ dynamics and the system response to adjusting fertiliser rates.

Figure 1 shows that the vast majority of these LTEs are to be found in developed countries, particularly in North West Europe. With the severity of issues of food security and population pressure likely to be greatest in the tropics of the developing world it is important to ask whether there is sufficient information available from LTEs in these regions. A recent synthesis of LTEs in Africa demonstrates that LTEs do exist in this region, but it is key that these are properly resourced [66]. LTEs in Africa have been established in a wide range of soil types and agroecological zones. The crop targets are generally different from those in temperate regions and include maize, sorghum, and millet. With the awareness of nutrient limitations there is also a focus on legumes including beans, cowpea and groundnuts. Many are managed under the umbrella of integrated soil fertility management which seeks to decrease reliance on inorganic fertilizers and include the recycling of nutrients as manures and 
composts [66]. It is now time for a global effort to instigate and resource existing LTEs in the tropics in systems where the greatest pressures of population, climate and resource degradation are likely to be felt.

The majority of established LTEs were set up to answer a specific question relating to fertiliser rates, organic versus mineral fertiliser types, tillage, soil carbon dynamics or cropping sequence, and were continued after answering the initial hypothesis as more general long-term value was realised. More recently, however, it has become apparent that these management interventions rarely operate in isolation to the wider production system, and a need for whole-system experimentation that incorporates elements of rotations has been identified. With many LTEs the management retains the original experimental design leaving practices that do not reflect modern agriculture. To address current concerns about food security, loss of biodiversity and the long-term future sustainability of managed systems, a number of new research platforms have been established that are designed to assess whole-system responses to new management approaches and to identify trade-offs, conflicts and synergies across different components of agricultural systems. These experiments use contemporary management, setting them apart from older experiments, and have longer-term intended lifespans than single or two year experiments that dominate soil management and plant breeding research.

\subsubsection{Centre for Sustainable Cropping (CSC), The James Hutton Institute, East Central Scotland}

The CSC is a 42 ha site, established in 2009 as a long-term platform for cross-disciplinary research on arable sustainability [67]. The general aim was to design a sustainable cropping system that, over the course of multiple six year rotations, tests and demonstrates the optimisation of inputs, yield, biodiversity and ecosystem processes (e.g., photosynthesis, carbon and nutrient transformations and fluxes, decomposition and community dynamics). The effect of the sustainable management system on long-term trends in yield and system health is being assessed relative to standard conventional agronomic practice. The CSC also provides a field-scale test-bed for new "sustainable" crop varieties designed to enhance nutrient and water use efficiency, weed suppression, and pest and disease resistance.

\subsubsection{North Wyke Farm Platform (NWFP), Rothamsted, South West England}

The NWFP for agri-environmental research in temperate grassland is a set of 3 hydrologically isolated farmlets, each of approximately 22 ha, established in the UK in 2010 to assess agricultural productivity and ecosystem responses to different management practices [68,69]. Research topics covered include $\mathrm{N}$ fertiliser replacement by legumes, phosphorus cycling, soil resilience, carbon cycling and sequestration, water use efficiency and systems modelling.

\subsubsection{NIAB (National Institute for Agricultural Botany) New Farm Systems (NFS) and Sustainability} Trial in Arable Rotations (STAR), SE England

NFS and STAR were established in 2007 and 2005, respectively to investigate changes in soil management from conventional ploughing to shallow or deep non-inversion tillage. The focus of STAR is the efficiency of a range of arable crop rotation options, whereas NFS investigates fertility building and energy efficiency through the use of cover crops or organic amendments. The experiments are replicated and randomised, with treatment plots $>10 \mathrm{~m}^{2}$ in size. Although both experiments have 
been in place for several years, they rely on funding from charitable trusts and research grants, so their longevity is uncertain.

\subsubsection{ORE-ACBB (Observatory for Environmental Research-Agroecosystem Biochemical Cycles} and Biodiversity), INRA, France

The three agricultural ORE sites are Theix (natural grassland site, established 2005), INRA Lusignan (mixed farming systems, established 2005) and Mons en Chaussee (arable cropping, established 2009). All focus on the management impact on $\mathrm{C}$ and $\mathrm{N}$ cycles and vegetation dynamics and gathering data to investigate system resilience following anthropogenic perturbation such as tillage and plant cover removal [70]. The aim is to support interdisciplinary research on the long-term evolution of the soil-vegetation system under contrasting management regimes across the three sites.

All experiment sites, whether more recently established farm platforms or traditional long-term experimental sites, have the disadvantage that they may not represent conditions in real commercial farms. Variation in soil type, climate and topography may not be represented well at any one site. Replication may be limited. Spatial scale and extent may also be unrepresentative, resulting in a misrepresentation of dynamics at the field and landscape scales. Smaller plot size is also likely to interfere with the use of standard commercial scale equipment which may also influence the outcome of experimental trials. Care must therefore be taken in the generalisation of results from experimental sites and some element of ground-truthing is required in order to validate experimental data.

\subsection{Farm Scale Evaluations}

Ground-truthing of LTEs should take the form of large-scale surveys of commercial farms where soil properties, environmental and ecological variables, crop parameters and agronomic inputs can be used to test results gained from experimental platforms. This testing is common in commercial plant breeding with on-farm assessment used to confirm, or otherwise, the characteristics of germplasm identified as elite before the release of varieties to the market. Single year surveys on commercial farms can also be used as space-for-time substitutions for longer term studies on more realistic sites, thereby producing more generalized results. Examples include the nation-wide Farm-Scale Evaluations between 2000 and 2003 where 266 fields across the UK were surveyed to assess the environmental (biodiversity) impact of the cultivation of genetically modified, herbicide tolerant GMHT crops [71,72]. The large number of sites included in this survey resulted in consistent patterns in response variates across the UK, taking into account wide variation in local soil and environmental conditions. Similarly, a more recent survey of $>100$ arable fields in Scotland was used to identify changes in soil, plant and invertebrate indicators across a management intensity gradient [28,73]. In the Netherlands, a similar large scale survey of 147 farm holdings across five agricultural regions was conducted between 1993 and 1997 to compare conventional, organic and integrated winter wheat production systems [74]. Significant relations between variables at these large spatial scales over short timescales can be used to validate data gathered from smaller scale experimental manipulations over long periods. Common garden style field trials are therefore also an option $[75,76]$. However, high quality, extensive 
and detailed, relevant and appropriate phenotyping needs to be associated with the genotyping and accurate agronomic data obtained from farmers to enable it to be exploited successfully.

\section{Methods for Phenotyping Plants and Crop Response to Management and Environment}

Phenotyping is the categorisation and quantification of the physical or biochemical variation of organisms. At its most basic, field based phenotyping for crops involves the analysis of yield variability due to changes in genotype and/or environmental conditions caused by differing sites, management or year to year variability. Yield is a very rapid assessment that can be measured on the move with modern harvesting equipment, but yield depends on many factors over the life cycle of a plant, and to some extent its parents' life cycle. To deconstruct the multiple effects that drive crop yield multiple elements of a plant's structure, chemical makeup and development need to be measured or phenotyped in multiple characterised environments. By understanding more of the processes that drive yield, it is also possible to disentangle other interactions between plants and their environment that might drive functions that lead or contribute to the provision of ecosystem services.

Field based plant phenotyping goes far beyond yield and can include the quantification of plant structure, development, growth rate, biochemical and physiological status. Phenotyping is commonly conducted in multiple environments to provide a range of soil properties and climates to minimise potential bias from site-specific effects. It is also used in experiments exploring plant responses to soil management and farming practices such as inputs of nutrients, water and pesticides. The latter may also include phenotyping for disease progress. More controlled conditions for plant phenotyping are possible ex situ using glasshouses and controlled environments, and/or specialized growth media (e.g., aeroponics, gels and transparent soils [77-80]). These environments also provide an opportunity to conduct measurements that are not possible in the field (Table 1). Phenotyping methods are often divided into invasive/destructive methods and non-invasive methods, and although invasive and/or manual phenotyping methods are still widely used [81-83], the drive to phenotype larger populations under many different conditions and the more variable phenotypes of field grown plants compared with controlled environment grown plants has led to a push to develop automated non-invasive systems [77]. The generation of large data flows from these automated and integrated phenotyping systems requires the parallel development of high throughput data acquisition and analysis methodologies, with potential steps in the phenotyping process including sample extraction, imaging or chemical analysis, extraction of relevant data from image or analysis data stream, classification and storage of data and finally, statistical analysis.

\subsection{Invasive Methods}

Traditional invasive methods include collection of both the above and below ground parts of the plants, for both biomass measurements (including partitioning into yield vs. vegetative parts of the plant), size determination and shape determination (e.g., tiller number or length) and root mass. This may also include scores of development using numerical scales such as the Zadoks scale [84]. Root systems in particular are still more commonly phenotyped via invasive methods that are time-consuming and produce considerable data from scanned images of excavated root systems. Scanning produces data on root size, length and branching angles using cheap and readily available 
flatbed scanner technology and utilising image analysis software such as the freely available imageJ or specialised software Winrhizo to extract root length density from extracted roots or for leaf shape analysis $[85,86]$. Higher throughput systems for harvesting and processing of samples in the field to assess plant root properties have been developed that greatly increase the processing speed of samples, enabling the analysis of populations large enough to allow Quantitative Trait Loci (QTL) analysis of maize for example [87]. An alternative method to the extraction and measurement of root biomass distribution is the extraction of DNA directly from soil, followed by PCR-based methods using plant specific primers to quantify the plant DNA $[88,89]$. These techniques need to overcome issues of soil core extraction, throughput, low and variable DNA yield caused by variation in DNA binding to soil particles and variation in DNA copy number between genotypes [90]. Invasive methods also bring the possibility of biochemical phenotyping to assess quality traits such as nutritional benefit, texture, taste and also the presence or absence of toxins and their response to, for example, alternative cultivation or nutrient treatments (e.g., Metabolic phenotyping of potato [91-93]).

Table 1. Phenotyping techniques and their applicability to the field.

\begin{tabular}{|c|c|c|c|}
\hline Phenotyping Method & Target & Field Applicability & Other Comments \\
\hline Flat-bed scanner & Roots/leaves & $\begin{array}{l}\text { Requires destructive } \\
\text { harvesting of sample } \\
\text { for field use }\end{array}$ & $\begin{array}{l}\text { Cheap technology and simple to use. Could } \\
\text { be used from the back of a trailer in field but } \\
\text { will always be destructive for root samples }\end{array}$ \\
\hline $\begin{array}{l}\text { Rhizotron imaging } \\
\text { in tubes }\end{array}$ & Roots & $\begin{array}{l}\text { Tubes require installation } \\
\text { prior to extensive crop } \\
\text { growth, therefore limited to } \\
\text { small scale experiments }\end{array}$ & \\
\hline X-ray/MRI & Roots & $\begin{array}{l}\text { Only applicable to samples } \\
\text { removed and scanned ex situ }\end{array}$ & \\
\hline $\begin{array}{l}\text { DNA extraction for } \\
\text { biomass analysis }\end{array}$ & Roots & $\begin{array}{l}\text { Requires coring for soil } \\
\text { samples and destructive } \\
\text { extraction of root DNA }\end{array}$ & $\begin{array}{l}\text { Requires extensive calibration of samples to } \\
\text { specific soil type and number of sequence } \\
\text { copies if multiple genotypes are } \\
\text { being investigated }\end{array}$ \\
\hline Light based imaging & Shoots & $\begin{array}{l}\text { Can be done using simple } \\
\text { camera systems or via } \\
\text { imaging attached to trailers }\end{array}$ & $\begin{array}{l}\text { Can be very simple to use but can suffer } \\
\text { from variable light conditions/shadowing and } \\
\text { reflectance causing downstream image } \\
\text { analysis issues. }\end{array}$ \\
\hline $\begin{array}{l}\text { Infra-Red } \\
\text { methodologies }\end{array}$ & $\begin{array}{l}\text { Shoots via } \\
\text { root linked } \\
\text { physiology }\end{array}$ & $\begin{array}{l}\text { Has been used at a range of } \\
\text { scales from individual leaves } \\
\text { to field scale. }\end{array}$ & $\begin{array}{l}\text { Is affected by variable temperature When } \\
\text { insinuating links to roots size careful } \\
\text { interpretation of correlations is need }\end{array}$ \\
\hline $\begin{array}{l}\text { Laser scanning } \\
\text { Biomass }\end{array}$ & $\begin{array}{l}\text { Shoot } \\
\text { shape/biomass }\end{array}$ & & \\
\hline Capacitance & Roots & $\begin{array}{l}\text { Measures individual plants } \\
\text { system requires plant contact }\end{array}$ & $\begin{array}{l}\text { Originally considered to measure root } \\
\text { biomass but now shown to measure a cross } \\
\text { section of roots diameter at soil contact }\end{array}$ \\
\hline Electromagnetic & Roots & $\begin{array}{l}\text { Requires wires across field } \\
\text { but suitable for small plots. } \\
\text { Non-contact therefore } \\
\text { application to field use }\end{array}$ & \\
\hline
\end{tabular}




\subsection{Non-Invasive Methods}

The need for higher throughput phenotyping in both contained and field environments has led to a demand for non-invasive methods utilising imaging and image analysis technologies. The successful implementation of these methods requires imaging in 2D or 3D and includes the use of visible and infrared based systems, laser and light sheets together with X-ray, electro and magnetic systems for below ground visualisation. Images must then be processed with extraction of relevant image information via segmentation, classification of the plant shape [94] recognition of the specific plant part and separation of plants parts (for example, P TRAp: a panicle trait phenotyping tool enables the extraction of panicle structure, spikelet/grain counting and seed shape analysis [95]). Advances in this area include the extraction and classification of plant organs from datasets obtained using 3D laser scanners [12], for example, they were able to separate and classify grape vine leaves to an accuracy of $98 \%$ and separate wheat ears from the rest of the plant with an accuracy of $96 \%$. Further, using specific wavelengths that measure the maximum quantum yield of photosystem II, chlorophyll fluorescence imaging has been used to phenotype plants for disease resistance by measuring the very early signs of disease progress [96]. This type of measurement can also be used as an indicator of plant stress. Ideally the measurement system should also allow frequent passes across the cropping area such that phenotype can be linked to crop development and environmental weather patterns.

Root systems can be measured in pot-grown plants or extracted soil cores using X-ray Computer tomography [97]. The resolution depends on sample size, but pots $10 \mathrm{~cm}$ in diameter can be measured to about $30 \mu \mathrm{m}$ resolution, with resolution as fine as $0.4 \mu \mathrm{m}$ possible on sub-cm sized tubes imaged with X-ray Synchrotron radiography [98]. Detecting root systems in X-ray images is difficult, although recent image analysis methods are improving in reliability [97,99]. Multiple X-ray computer-aided tomography (CT) systems are now being established in parallel to enable the rapid phenotyping of plant roots of different genotypes grown in a range of soil conditions.

\subsection{Translation of Methods for in Field Phenotyping}

The ability to translate phenotyping methodologies to the field varies (Table 1). Despite significant advances in the use of automated imaging technologies within controlled environment systems, variable environmental conditions cause difficulties in translating methods to the field. Some imaging techniques suffer from problems due to variable lighting conditions including, for example, non-consistent lighting conditions creating shadows and reflected specularity (bright spots) and variation between successive images. Thermal imaging can be affected by surrounding temperature and humidity [100]. These can cause problems in image analysis processing as consistent thresholding cannot be used to extract the plant information from background [101]. Solutions can lie in using alternative imaging methods that use specific wavelengths that are not sensitive to environmental light variations [102] or normalisation of data by using overlapping images and difference from mean of image statistical methodologies [103]. Remote sensing and close-up techniques have also been developed for the detection of diseases. Both techniques have proved useful due to the patchy nature of disease outbreaks within crop stands in the field [13].

Root phenotyping gives particular difficulties for non-invasive phenotyping in field. Often indirect correlations between above ground traits and root behaviour are utilised by investigating root-linked 
processes, e.g., differences in stomatal behaviour at the leaf through to field scale have been linked to temperature of plants and correlate with variation in tolerance to stress at the genetic level. Differences in stomatal activity in Solanum tuberosum has been shown using thermal imaging to have a negative correlation between canopy temperature and final tuber yield under non-limiting water conditions [103] and thermal infrared imaging of crop canopies has been used for the remote diagnosis of water stress [104]. It has also been used to assess the effectiveness of different management strategies on crop water status [103]. Comparison of more simplistic IR thermometry on dense crop stands to more sophisticated thermography methods has found similar results [105]. Other methods include the association of water spectral indices with plant and soil water relations in contrasting wheat genotypes $[106,107]$ and laser-induced chlorophyll fluorescence for nitrogen status and biomass determination [108,109].

While systems such as X-ray $\mu$-computed tomography are a significant advance for understanding the interaction of roots with soil under controlled environments these technologies have significant safety issues outside of contained environments. Light based camera and scanner based technologies have been successfully employed in a limited way infield or in contained (larger) soil systems via the use of clear rhizotron tubes inserted into the soil environment. Time lapse images are obtained as root growth passes the clear tubes and are analysed for new root appearances. While giving information on, for example, the development of the meristem front, the number of tubes that can be used under a field situation is limited. There are also issues of soil disturbance in and around the tubes as they are installed. There has also been an interest in developing capacitance or electrical based methods of measuring below ground processes such as electrical resistivity tomography or electromagnetic induction [110]. Electrical resistivity tomography has been used to show differential drying under wheat plots suggesting variation in root water absorbance rates. However, interpretation of exactly what is being measured can be difficult and differences in measurements are often found between controlled environment measurements and field results. Thus, in order to understand differences, methods should be fully validated to ensure the correlations are applicable in the conditions being used [110-112].

While many QTL analyses study phenotype for a single trait, the analysis of multiple traits has been found to be useful in understanding the responses to, for example, nitrogen supply [113]. With the recent move to high throughput computing and computer assisted trait measurement and categorisation a parallel move combining field based imaging and measurement techniques has occurred [114].

Tractor based systems or bespoke robot systems have been developed to allow the parallel utilisation of several techniques during a single crop pass. For example BreedVision is a multisensory tractor-pulled device that has been developed to include light curtain imaging, 3D time-of-flight cameras, laser distance detectors, hyperspectral and colour imaging integrated in one system [115]. The system has been used to assess biomass accumulation of 647 doubled haploid triticale by combining the output from the multiple sensors [115]. Multiscale imaging can also give an alternative view of response process when combining, for example, small scale leaf measurements with crop scale imaging [116]. While some progress has been made in the integration of the field instrumentation required for measurement capture during phenotyping [37], there is also a need for integration of the data to allow further analysis of datasets [117]. The quantity of data produced also means that it is necessary to assess the processing and integration time and introduce methodologies such as 
"mesh based quantification" of plants that was shown to reduce time taken to analyse an individual plant [118]. While phenotyping data output from these systems will give us better understanding of the overall growth and stability of phenotypes in field it is necessary to keep accurate records of climate data, and also acquire environmental data relating to the management effects, such as tillage on soil structure, such that these can be linked back to crop phenotypic changes. Further, systems need to be put in place that allow the integration of the phenotyping data and environmental data across different platforms [119].

\subsection{Characterising Soil Conditions for Plant Growth in the Field}

Modern experimental platforms that are used to identify crop genotypes suitable for new forms of soil management, greater resource use efficiency and improved soil sustainability require detailed characterisation of a range of soil properties. One of the greatest impacts of tillage on crop productivity is through changes in soil physical characteristics, including the potential development of shallower plough pans that may be off-set by an enhanced capacity of soil to regenerate structure through biological processes and weathering [120]. There is a range of methods to measure soil physical conditions for crop growth that vary in complexity from assessments related to restricted root growth [35,121] and nutrient capture [122], to simple visual assessments of the structural state of soil [123]. Many of the laboratory assays use new approaches to integrate and analyse soil data that is regularly collected [124-126]. $S$ theory, for instance, uses the shape of the soil water retention characteristic to provide a simple, quantified measurement of pore structure scaling. The $S$ value has been related to various agronomically significant properties such as fragmentation by tillage, structural degradation of seedbeds [126] and the response of cereals to soil conditions [127]. A more widely adopted indicator is the Least Limiting Water Range, LLWR [128,129]. It uses cut-off values of soil water content based on hypoxia, drought and mechanical impedance, to define the range of soil water contents where soil properties will not severely impede crop productivity. LLWR is based on several generalisations about soil behaviour that may not be observed under field conditions, where the structural heterogeneity of soil properties can have a large impact on crop productivity. For instance, LLWR defines $2 \mathrm{MPa}$ resistance to a cone-type micropenetrometer (with relieved shaft) as the cut-off mechanical impedance where root elongation is severely restricted. Field penetrometer resistance that limits oat root growth, however, was found to be 4.6 to $5.1 \mathrm{MPa}$ in untilled soil layers, as compared with 3.6 MPa for tilled topsoils [130] due to roots exploiting a network of continuous biopores in the untilled soil. Such pore networks enable roots to penetrate to depth in very hard Australian sub-soils, where wheat root growth is confined almost entirely to biopores [131]. It is therefore apparent that there exists scope to develop better soil quality indicators that describe limitations to crop productivity.

Both $S$ theory and LLWR are too expensive and time-consuming for widespread adoption, so other simpler indicators have also been advocated. Many confirm, albeit under modern production systems, long-standing understanding about soil constraints to crop productivity [29]. The available water and air-filled porosity at field capacity has been related to yield and soil quality across numerous experimental farms in Canada [132]. In recent research, air-filled porosity was related to seedling root elongation in an assay of soils from numerous commercial farms in the UK [28]. On-farm assessments have been refined through the development of visual assessments of soil structure [123]. Visual assessments have also been related to yield efficiency and offer the advantage of a simple spade 
test [133]. Although a visual assessment is a useful component of a farm-based assessment, particularly to identify good and bad areas within a farm, it is too subjective and qualitative to disentangle underlying properties of soil that may be limiting yield and describe genotypic specific responses to soil conditions [29]. Various groups have therefore combined more quantitative soil quality indicators with visual assessments of soil structure, including in-field assays combined with penetrometers and laboratory measurements of a range of soil properties and these have recently been reviewed [134]. In fact, smart phone applications have recently been developed which allow farmers to gain rapid information about the properties and SOC content of their soil by submitting an image of their soil to the application [135].

\section{Specific Crop Trait Requirements of Different Management Systems}

\subsection{Organic and Low-Input Systems}

The characteristics of organic agricultural systems in comparison to conventional systems have been extensively reviewed elsewhere [122], but, briefly, these include a range of potential benefits, such as biodiversity at soil, crop, field and landscape level and the greater focus on integration of crop and livestock production systems on the farm compared with conventional farming systems [136]. The greater biodiversity of organic farms is thought to provide a range of ecosystem services that enhance farm resilience to a large extent and reduce environmental impact [137,138], although there are some pedoclimatological conditions when the organic systems have negative environmental impacts such as on steep slopes [138]. Moreover, the benefits of organic agriculture vs. conventional agriculture are sometimes questioned due to issues associated with reduced output and therefore carrying capacity of the agricultural system and the potential impact on food security, along with inappropriate use of organic inputs leading to point source pollution of the environment [139]. The potential impacts on food security are clear when it is demonstrated that on average organic systems tend to achieve between $60 \%$ and $95 \%$ the yield of their conventional counterparts and this is the case for a large range of crops including cereals, root and tuber crops, pulses, oil seeds, vegetables and fruits [140]. Because herbicide use is not permitted in organic systems, control of weeds leads to greater soil disturbance by e.g., cultivation and flame treatment than occurs in conventional systems. This extra disturbance and the associated more frequent machine traffic is a risk to soil quality in organic systems [141]. The severity of negative impact of organic systems is likely to be dependent on geographic location and therefore likely to be affected by environmental and economic factors [140].

Regardless of the benefits or not of organic agriculture there is a demand for the products from this enterprise in the developed world, at least, and this demand has been increasing in recent decades [142]. So there is an incentive to breed varieties of crops specific for organic systems, which may go some way to ameliorating the potential negative implications of organic systems [143]. To date, only a few varieties of arable crops have been specifically bred for organic and low-input systems, and although breeding in organic systems is starting to happen in the arable sector [143], there are apparently no such moves for pasture and forage enterprises [144] although the differences between conventional and organic systems in pastures are thought to be much smaller than arable systems [145]. It is estimated that more than $95 \%$ of organic agriculture is based on crop varieties that were bred for conventional high-input systems with selection having been made in conventional breeding 
programmes. Recent studies have shown that such varieties lack important traits required under organic and low-input production conditions [39,125,146,147].

While many traits which should be targets for breeding for organic agriculture, such as yield, resistance to biotic and abiotic stress, processability and qualities associated with taste and health do not differ from conventional varieties, their expression under low-input conditions is not necessarily guaranteed if selection is performed under conventional conditions [148]. Importantly, there is also a range of traits which are very specific to organic systems and would never be selected for in conventional systems, which include increased competitiveness against weeds and resistance to seed-borne diseases [148]. Notwithstanding this, the biggest issue with selecting organic varieties under conventional conditions is that many of the desirable traits selected for are detrimental in low-input systems $[142,148]$. Since the green revolution in the 1950's one of the focuses of breeding has been improving yield by increasing the harvest index. In cereals, this approach has resulted in (1) reduced early growth, size and depth of root systems [149]; (2) increased reliance on high inorganic-N inputs to attain satisfactory protein contents [150]; (3) reduced nutrient-use efficiency [151]; (4) decreased competitiveness against weeds or decreased robustness against mechanical weed control (and thereby greater reliance on herbicides) [152]; (5) greater susceptibility to diseases [153] such as powdery mildew [154], Septoria [155] and Fusarium [156]; and (6) reduced protein content [157].

In order to effectively screen and breed varieties for low-input or organic systems the genotypes need to be selected under organic or low input conditions, which requires the availability of long-term platforms including a large range of organic systems in a range of environments [142]. Such a concept may invoke a participatory approach [143] or even the development of modern landraces ideally suited to specific farmers' systems [143,158]. Location-specific adaptation of these diverse landraces and elite populations will be important for further selection at the individual farm level. New strategies are emerging to produce "modern landraces" based on multiple cross populations of einkorn, emmer and bread wheat in combination with on farm site-specific selection to obtain highly adaptable populations for local and regional production [158].

Regardless of how the selection of useful varieties takes place, there is a need for effective ways of screening a number of key traits including nutrient use efficiency, rhizosphere competence for disease suppression, tolerance to mechanical weeding, tolerance to seed and atmosphere-borne fungal and bacterial diseases, insect resistance, tolerance to abiotic stress and nutritional and processing quality $[148,159]$. Specific targets will therefore need to be identified and are likely to include: adaptation to fluctuating nitrogen dynamics; efficiency in capturing and utilising water and nutrients; deep, extensive root system; ability to interact with beneficial soil micro-organisms (mycorrhizae and nitrogen fixers, pathogen antagonists); shoot architecture for early soil cover and more light capture; resistance to mechanical weed control; durable disease resistance; combining ability for crop and variety mixtures; high germination rate; seedling shoot and root vigour; early maturation; lodging resistance; adaptation to local climate and latitude; necessary processing quality; beneficial taste traits; long storage potential and yield stability under low-input conditions [142,159]. It is obvious that the list of potentially important characteristics is large and impracticable to consider one by one. Wolfe et al. [143] suggest a number of ways in which this could be rationalised: (1) Identify pleiotropic characters that may have a positive value for a wide range of physiological needs, for example early vigorous growth which impacts weed suppression, disease resistance and nutrient 
capture; (2) Concentrate on characters that integrate many minor and variable characters, such as yield; (3) Identify characters that contribute to the system as a whole e.g., root systems that promote beneficial soil structure and nutrition for subsequent crops; and (4) Consideration of traits which allow growth in mixtures or polyculture.

Whatever the final prescription for the target or range of traits to be targeted in breeding for organic or low-input agriculture it is absolutely necessary that these are trialed and selected in environments that are representative of the system long term, i.e., in appropriate long term field platforms and that the relevant trait phenotyping approaches are developed so these traits can be screened effectively in the field.

\subsection{High-Tech Systems including Precision Agriculture and Controlled Traffic}

A primary target for conventional agriculture has been to create crops that are uniform at the scale of the field. Harvesting can then be conducted with minimal losses and maximum efficiency. This is particularly the case for crops that can be stored post-harvest. For example, a key reason for cultivation is to produce a homogenous seed bed that will favour uniform germination and emergence of cereal crops with the hope that maturity is reached with similar consistency. Precision agriculture aims to improve the crop uniformity at harvest by measuring soil and crop conditions at the sub-field scale and delivering management in response to quantified differences [160]. This measurement may be done pre-planting including yield mapping from previous crops or may be real-time, based on sensors attached to the machinery delivering any agricultural activity [161]. Thus in precision agriculture the depth of cultivation and application of water, nutrients, herbicides and other pesticides may be varied in response to quantified differences in soil conditions and crop development at the sub-field scale [162]. With improvements in sensors for crop and soil conditions, data from remote sensing, location within the field precisely identified by Global Positioning Systems (GPS), faster and more powerful computing that can change application rates sufficiently quickly to react to real time information at the speed of agricultural machines, precision farming offers opportunities for improved efficiency in resource use [163]. While the term precision agriculture has existed for at least 30 years, its continued development means that there are no long-term platforms (or experiments) deploying precision agriculture as it is currently understood.

Another development in recent years is that the mass of agricultural machinery has increased and continues to do so. As the cost of labour increases there is a need to prepare and plant greater areas per man-hour and this has favoured the use of larger machinery. Axle loads in excess of $10 \mathrm{t}$ are now common as part of cereal production through much of European agriculture and are often well in excess of this for production and harvesting of root and beet crops [164]. Such large traffic loads moving over the vast majority of a field within any season creates compacted zones within the soil. These zones are not plough pans as they can occur under any cultivation system. Soil physical impedance and waterlogging are associated with traffic of agricultural machinery and in the introduction above we noted that they limit root proliferation. Controlling the movement of agricultural machinery, as in Controlled Traffic Farming (CTF), can be achieved in a variety of ways but the advent of precision farming, and the use of GPS in particular, increases the options to deploy CTF [165]. Precision agricultural systems using driverless machinery steered by programmed guidance systems are under testing and these may offer the opportunity to move to farming systems with more but lighter 
machines [166,167]. Diversity in machine types and traffic controls allows different soil conditions to be created or to develop over time and thus provide different environments for root proliferation.

The principles of precision agriculture are not antipathetic to low-input agriculture [168], but in practice they have often been incompatible. Precision agriculture, as typically practised, requires the machinery used on farm to have GPS location and some form of computer control for the delivery of agro-chemicals with resultant need for capital investment beyond that available to most practitioners of low-input farming. However the ability to precisely target inputs and to apply the minimum required, as is the objective of precision agriculture is consistent with low input systems. Further the ability to rapidly sense and quantify crop stress (e.g., as Normalized Difference Vegetation Index) and deliver inputs in response to that stress, as is possible with precision agriculture, is likely to be useful in field phenotyping [169]. If lighter, less-energy demanding machines become more common the opportunities for precision agriculture in low-input systems becomes more viable. There exists the opportunity to use the principles of precision farming to inform low input and other systems. Given cost implications of equipment associated with precision farming this may be done in a research setting such as a long-term platform.

It is apparent that a primary aim of high-tech interventions is to homogenise production and hence improve efficiency. The traits required for plant growth in optimal conditions may be similar to those aspired to in conventional agriculture and so there is the potential that material from breeding programmes and phenotyping platforms designed for conventional systems to be appropriate for high-tech systems - but this is yet to be confirmed. While many environmental benefits (e.g., decreased gaseous emissions, water runoff and fuel use) are attributed to controlled traffic and precision farming the impacts on nutrient leaching and carbon storage are not well documented [170]. Research on long-term platforms under high-tech management should contribute to linking production with improved environmental outcomes.

\subsection{Polyculture vs. Monoculture}

Most of our high input cropping systems are monocultures. Even improved pastures normally utilize one of just a very few genotypes or species. This is because the greatest yield and quality is obtained by growing elite germplasm coupled with fertiliser and other agrochemical inputs such as herbicides, fungicides and growth regulators and thus returns greater profits. However, when these input and germplasm costs increase, profit can rapidly decline to a loss as such crops are often dependent on these inputs to be profitable and cannot be sustained at reduced input levels. By contrast, subsistence agriculture relies upon fewer non-renewable inputs but instead exploits genetic diversity for resilience [158]. Thus crops are frequently either mixtures or populations in such situations, and similar benefits can be exploited in more intensive arable cropping systems too. By processes of competition, compensation and facilitation, the yield achieved in polycultures is at or above the mean of the components grown separately [133]. Perhaps as importantly, resilience to stress, particularly biotic stress caused by pathogens, is enhanced in many mixtures. In the case of pathogens with high expressions of host specificity such as the powdery mildews, this is achieved through barrier effects or resistant genotypes, dilution of susceptibles and induced resistance [146]. These benefits of heterogeneity are expressed within crops but also up the scale to fields, farms and landscapes. In some 
systems such as agro-forestry or permaculture, such heterogeneity is designed into the system predominantly using different species and plant types such as trees and arable crops.

Mixtures that perform best whatever the scale tend to be composed of individuals with contrasting traits. In specific cases such as resistance to pathogens with specificity we know something about the nature of the traits and how they interact with the environment, whether it is the weather or population structure of the pathogen (e.g., [35,171]). However, where traits and/or the environment are more difficult to assess, particularly below-ground, we know very little. Thus designing mixed genotype cropping systems is based more on principles than specific traits and parameter ranges. Nowhere is this more so than for traits that are important in the soil environment. As it is reasonable to assume that plant root trait interactions with each other and their biophysical environment will contribute to similar benefits to those achieved above-ground, this is an area of great potential that should be investigated more.

To investigate below-ground interactions we need suitable soil management platforms representative of current arable environments as well as extremes in soil conditions, whether beneficial or disadvantageous. Whilst our knowledge of root-microbe-soil interactions is increasing considerably, we have little knowledge of how heterogeneity of the root community itself impacts on these interactions. This is difficult to achieve in the field but controlled environment experimentation has demonstrated the potential importance. Using contrasting phenotypes of Arabidopsis thaliana in pots where the soil environment could be partitioned Creissen et al. [172] demonstrated that competition below-ground could be beneficial and intense. What the impact of varying soil environments would be on such interactions is unknown. Selecting contrasting seedling root phenotypes, barley mixtures were grown in all combinations of four cultivars under contrasting soil cultivation treatments for five successive years. The mixtures gave a significant benefit compared to their monoculture components but there was no interaction with the soil cultivation treatment [173]. However, it was later found that all four cultivars used show no consistent differential response to soil cultivation over a number of seasons with varying weather whereas some others did[173].

As well as direct response to root interactions, the root heterogeneity itself may have implications for the soil and rhizosphere microbial environment. Plant-arbuscular mycorrhizal fungal communities are known to differ between single species and heterogeneous communities and thus the previous cropping history could have a big impact on subsequent trials where plant performance is influenced by mycorrhizal colonisation (e.g., [174,175]). Soil cultivation treatment will obviously add another interaction layer to this. It seems likely that heterogeneous plant communities will have impacts on many aspects of soil microbial community composition and that soils from monocultures, particularly successive cereal crops for example, will skew the community structure in particular directions. In the same way cropping sequence or rotation will impact the soil community, with for example, glucosinolates from brassica roots having particularly strong effects [37]. However, root exudate differences, even between different spring barley cultivars, influence communities of nitrifier and denitrifier bacteria [176] and, thus, mixed root genotypes might be expected to influence nutrient availability in general. Thus experimental platforms having particular or exaggerated crop histories might be expected to reveal useful or informative interactions, but in all situations the crop and agronomic history should be taken into consideration in interpreting data. Under continuous heterogeneous barley and minimum cultivation, for example, we find that certain barley cultivars can 
be favoured, giving unusually high yields compared with other cultivars and standard cultivation [173]. Such findings may lead to selection of novel traits with greater resilience towards particular stresses.

The complexity of plant traits required for polycultures is much greater than in monocultures and the traits are unlikely to be the same as those which are beneficial to conventional or low-input monoculture systems, such considerations have recently been reviewed by Brooker et al. [177], where all the various interactions necessary for intercropping, polyculture and mixtures have been catalogued. So, specific phenotyping platforms and breeding programmes are required for crop genotypes for polycultures, whether these are intra- or interspecific polycultures. Consideration will need to be given to the range of traits that will be required to achieve niche complementarity, i.e., the optimal above and below ground traits which allow additive and synergistic interactions rather than competition. Although complex, this type of selection and breeding is starting to happen, such as the participatory efforts to produce modern landraces from farm saved seed [158]. Also, large breeding companies are starting to breed for polycultures, e.g., KWS, Germany have begun a breeding programme to select optimised maize and bean varieties to be grown in polycultures designed for biofuel production. It is therefore imperative that specific selection platforms and breeding programmes are designed if polycultures are to effectively replace current conventional systems.

\section{How Do We Deal with $\mathbf{G} \times \mathbf{E} \times \mathbf{M}$ in the Field?}

\subsection{Timescales for Establishment and Assessment}

Farmers and breeders have control over a number of management parameters that could affect the performance of specific genotypes. In field experiments, changes in practice such as fertiliser rates can have immediate impacts but the effects of tillage on soil properties [41] and weed populations [178] may take several years to show noticeable differences and continue to change gradually over time. Organic amendments also cause continual changes over time, with effects such as the potential build-up of toxic compounds, shifts in soil microbial populations and changes in soil structure, taking years to develop [179]. Crop rotation effects, particularly when continuous or short-rotations are employed, can exacerbate pathogen impacts over time, particularly under reduced tillage where residues may build-up on the surface $[180,181]$. Cover crops and preceding crops may have secondary impacts on building soil structure, fertility and carbon that also develops over time [175].

Time is also important to assess environmental effects driven by climatic variation. In the Amato et al. [180] study of long-term effects of soil tillage on crop productivity and quality in a Mediterranean climate, it was found that there were large differences in yield depending on soil water availability during a growing season (Figure 2). In wetter years a yield deficit under reduced tillage was found, which was also found in an analysis of over 200 experimental years of Swedish sites where conventional and reduced tillage were compared [181]. However, in the study of Amato et al. [180] the trend reversed in drier years when the capacity of reduced tillage soils to store more water had a positive impact on yield. The yield of different barley genotypes under reduced versus conventional tillage was also found by Newton et al. [173] to differ between growing seasons, with one atypical year with a dry spring and wet summer showing very different trends to other years when soil water was less limiting. 
Figure 2. In a field experiment running for 17 years, Amato et al. [180] found that crop rotations and the occurrence of dry years (e.g., Year 3) had a major impact on grain yield differences (termed Delta grain yield below) between no-till (NT) and conventional tillage (CT). Continuous wheat (WW) followed a general trend of decreasing grain yield over time under NT soil tillage, whereas berseem clover-wheat (WB) and faba bean-wheat (WF) crop sequences were less affected by a conversion from CT to NT. Reprinted with permission from Amato et al. [180].

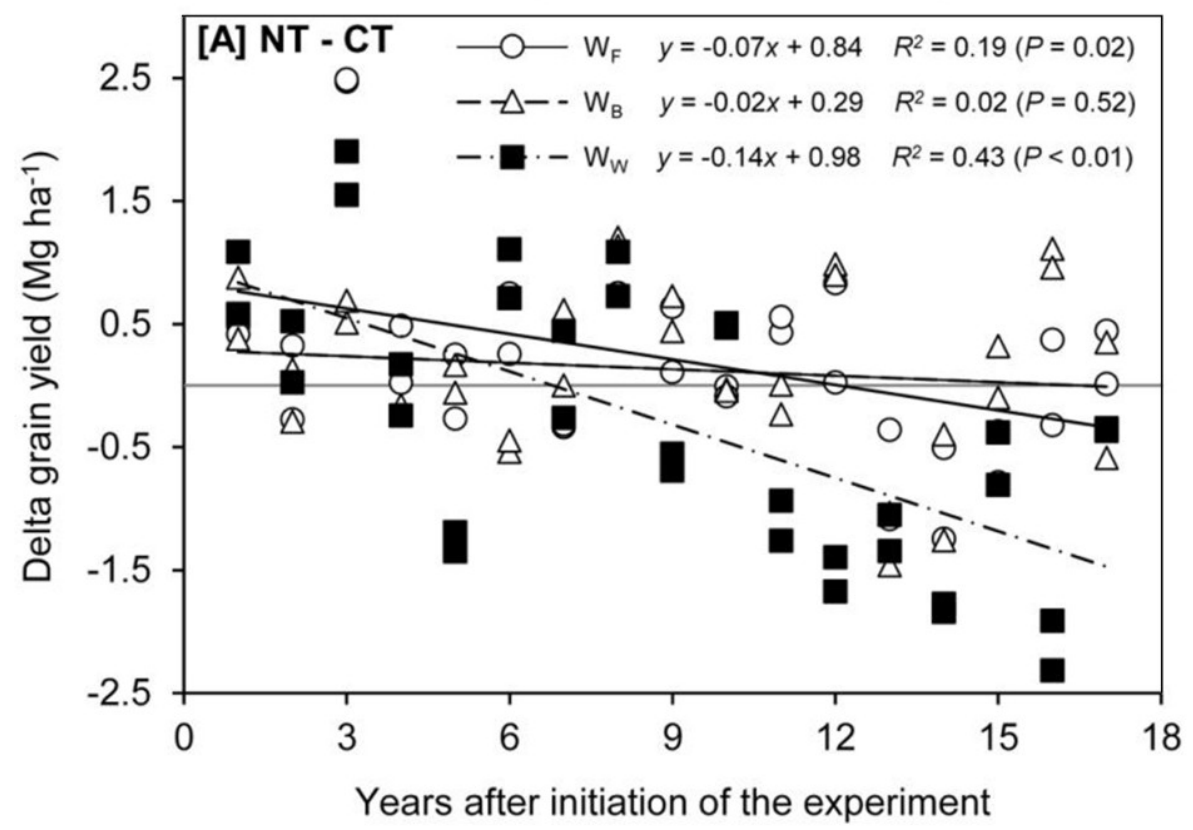

Based on the data presented above, at least five years are required before tillage or organic matter management impacts imposed in an experimental field platform can have noticeable impacts on crop productivity. Multiple years of data are also needed to account for the effects of climatic variability. For researchers this obviously presents a challenge, as present day funding systems are often only secure over much shorter time periods.

\subsection{Requirement for Crop Testing in Multiple Environments}

A debate to be had in the scientific, commercial and policy arena is whether there need to be separate breeding programmes to design genotypes (or ideotypes) of crops for specific environments, whether this be for organic, low-input, reduced tillage or polyculture. This is where field phenotyping and long-term platforms have a role to play. For example, we have evidence that phenotypes required for optimum nutrition and their underlying genetic control are quite different in barley under different tillage regimes [122]. This insight would not be possible without access to well managed long-term platforms for this management system. The efficacy of such approaches may differ for different traits. For example, for wheat, indirect selection under conventional high-input conditions is quite effective for traits with high heritability such as tillering capacity, early vigorous growth, earliness (heading date), some disease resistance, culm length, spike-length, and grain features such as thousand kernel weight (TKW) [143,148]. However, this is not necessarily the case for quantitative traits characterized by high genotype $\times$ environment interactions, like grain yield or end-use quality traits $[142,182]$. 
Based on a study of a segregating spring wheat population tested under organic and conventional farming conditions, Read et al. [183] clearly demonstrated the superiority of direct selection (under organic farming) compared with indirect selection (under conventional farming) for grain yield and yield components. The importance of taking into account the needs of the whole system when selecting crop varieties or traits for organic compared to conventional systems is imperative [143]. For example, crop nutrition may be influenced by the structure of the rotation along with appropriate agronomic interventions, so a crop variety selected to perform well with animal manure as a primary source of nitrogen may have very different traits to one selected to perform well using $\mathrm{N}$ fixed by a preceding legume crop.

Both biotic and abiotic stress treatments will be very variable from site to site and between seasons, so multiple environments are essential for robust experimentation. For example, many diseases are only recorded in some seasons whilst others vary in magnitude many fold between seasons. Furthermore, pathotype populations change imposing stress on different genotypes between seasons or environments, particularly for above-ground pathogens, but these will impact below-ground traits too. Similarly abiotic stress will vary between seasons in particular, but this can be interactive with soil status or treatment. For example, clear genotypic differential response to drought stress was observed between cultivation treatments for winter barley in one year but these were not detected in the absence of early season drought in a subsequent season, and only for a sub-set of genotypes in a later season[173]. Nevertheless, these responses identified genotypes with more robust trait expressions for further experimentation.

Without consideration of multiple environments, including multiple productions systems, it will be impossible to translate the gains made in genetic understanding of and breeding in crops to the real world farmer's field and would represent a huge waste of public resources if these latent benefits were not realized.

\section{Modelling for Better Management of Plants in the Field}

Long-term experiments and on site farm networks are creating large interconnected datasets of phenotype and environmental monitoring data opening up the opportunity for both interrogation of cross scale and cross platform datasets. The interrogation of these large or connected datasets for correlations between crop traits such as, for example, yield performance or drought tolerance and environmental indicator parameters such as the LLWR requires new tools in statistical analysis of multivariate data and also an ability to incorporate stochasticity into the analysis. This statistical understanding of changes in indicators or growth parameters, obtained during analysis of phenotyping or environmental monitoring data can be used to build models that both describe elements of the system, but also aim to test our understanding of the mechanisms and processes involved in the development of overall plant phenotype, yield or farm system outputs and health. Further, these can be used to test alternative scenarios, for example different climate conditions, which may be difficult to perform in practice. For example the long-term experiments and on site farm networks are creating large datasets that are being used to track, model and predict long-term changes in indicators for climate changes such as soil carbon and soil stability [44]. Models can vary in both scale e.g., from individual root/leaf or plant models, that attempt to describe and test the impact of biomass partitioning on plant productivity, through to field scale models that include some aspects of environmental impact 
or spatial variability. Depending on the scale and process it may be more or less relevant for the models to be more architectural based for example in the case of 3D plant architecture based models $[184,185]$ or be more density or processed based. Numerous models exist at each scale level from individual plant through to crop and field scale [184,186-195]-(e.g., APSIM and DSSAT include several different crop model modules [190,191,196,197]), while CROPSYST uses a generic model that allows multiyear simulations. Increasingly, attempts are being made to incorporate more elements into models such as changes in soil properties e.g., water budgets, nitrogen availability and bulk density or the elevated $\mathrm{CO}_{2}$ levels and elevated temperatures predicted by climate change models at both the individual plant phenotype scale and the field scale [184,192,193,198-201]. Inclusion of these parameters often also allows the calculation of parameters such water loss and $\mathrm{N}$ leaching [188,202]. Integration of models developed for different purposes or from different sources can prove challenging. However, efforts are being made to integrate, crop models by either recoding of models or via a modular approach such as including different crop, soil and weather modules allowing users to choose the elements most appropriate for their particular requirements [190]. Dynamic modelling environments such as STICS can also be useful [3]. One outcome of this modelling approach may be the development of phenotypic ideotypes suited to future environmental scenarios that do not, at present, appear in the collections of breeding germplasm due to the traits having been bred out of modern varieties. There is also the potential to use modelling to optimise phenotypes by including the trade-offs that occur between different plant traits (e.g., root:shoot partitioning) or within farming systems including the socio-economic consequences for farmers [203]. However, the development of ideotypes relies on a clear understanding of the processes involved in the system and it is likely that a range of types would still be required due to the variation in agricultural systems and potential future climate change scenarios. Modelling of processes and plant development will also allow the development of tools that will enable farmers to make assisted choices through tools developed specifically for on farm use. As the cost of phenotyping technology reduces it will be practical for farmers to increasingly use data obtained directly in their own fields, in season, to assist in choosing the appropriate management and crop combinations based on the local prevailing conditions and climate predictions. Combinations of long-term experimental platforms, accurate phenotyping and modelling will allow us to achieve this laudable goal.

\section{Translation of Results from LTEs and Phenotyping Platforms to Sustainable Production in Farmers' Fields}

Understanding of the complex relations between the soil, water, air and biotic components of managed systems is essential for designing sustainable production systems. To achieve this it is necessary to combine a number of different approaches: short-term small-scale experiments to elucidate mechanism, long-term platforms to establish long-term system responses, on-farm surveys to generalise results from experimental data, and modelling to predict likely future scenarios. Results from short-term, small-scale experiments on specific mechanisms or processes are readily translated into practice via field trials, such as variety trials. These experiments provide the evidence required for agronomic consultants and the industry to influence commercial farming practice in terms of selecting appropriate new varieties or applying specific management techniques. However, the responses of crop plants in these controlled, short-term and frequently single-variate studies may not translate directly 
to commercial field situations where multiple confounding variables are likely to influence the outcome of the new variety or practice. Long-term platforms specifically designed to test multi-variate, whole-system responses to the impact of new management practices and crop varieties are in their (relative) infancy since issues of sustainability and food security have only recently become priorities for funding. The long-term impacts on system sustainability and likelihood that emerging new cropping systems will be translated into commercial practice can only be ascertained after evidence has been gathered over several decades. At present the translation of demonstrations of benefit of processes, agronomy and genotypes from research stations and in experimental fields to real world farmers' fields is often poor and represents a significant bottleneck in the adoption of practices for improved sustainable practice. It is imperative that research is conducted to understand fully the $\mathrm{G} \times \mathrm{E} \times \mathrm{M}$ interaction so that the advances being made in plant genetics can be translated into a benefit in sustainability in agriculture. Development and maintenance of long term experimental platforms and field phenotyping techniques have a key role to play in achieving this goal.

\section{Conclusions}

- There is a need for a second green revolution where food security is achieved in a sustainable way.

- Testing genotypes in realistic field environments is critical to achieving translation of the understanding of traits at the genetic level to sustainable production in the real world.

- There is a large number of LTEs available to researchers in a range of production systems. However, these are mostly in the developed world. With the major global issues of food security and population pressure likely to be played out in the developing world it is important to ask whether we have enough information available from LTEs in the systems where the real pressures will be felt.

- There is a whole range of high- and low-tech options available for field phenotyping of plants to allow selection of appropriate traits and genotypes for a range of systems. However, systems need to be put in place that allow the integration of phenotyping data and environmental data including soil and climatic conditions from different platforms and this poses a data handling challenge which is yet to be solved.

- There is a whole range of agricultural systems which are poised to respond to environmental change through replacing conventional agriculture with high-tech solutions, low-input systems and polycultures. However, a debate needs to be had as to whether separate breeding programmes are needed to design genotypes (or ideotypes) of crops for these specific environments. This is where field phenotyping and long-term platforms that take account of seasonal and environmental variation have a role to play.

- Modelling has a role to play in both predicting the impact of changes to agricultural systems within the landscape of future environmental change and in the design of crop ideotypes for future agricultural sustainability.

- The translation of agronomic practices and beneficial genotypes from research stations to real world farmers' fields is often poor and represents a significant bottleneck in improving agricultural sustainability practice. It is vital that we understand fully the $\mathrm{G} \times \mathrm{E} \times \mathrm{M}$ interaction so that the advances being made in plant genetics can be translated into a benefit in the real world. 


\section{Acknowledgments}

This work was supported by the Rural and Environment Science and Analytical Services Division (RESAS) of the Scottish Government through Work Package 3.3, 3.4 and 5.2 (2011-2016). The work is also supported by the HGCA and Potato Council through grants funding projects "Platforms to test and demonstrate sustainable soil management integration of major UK field experiments (Platforms)" and "Soil platforms assessing the impact of potatoes in rotations on soil physical conditions" respectively and also through a Defra-Link project "New wheat root ideotypes for low input systems". The authors would like to thank Mark Young with assistance in generating the figures. The authors would also like to thank Ali Karley and Pete Goddard for useful comments on an early draft of this manuscript.

\section{Author Contributions}

Timothy S. George contributed to overall conception of the article, formulating the individual contributions into a whole narrative and edited the article incorporating comments from reviewers. In addition TSG contributed expertise in root phenotyping, low-input systems and $\mathrm{G} \times \mathrm{E} \times \mathrm{M}$ to the writing of sections 1, 4, 5, 7 and 8. Cathy Hawes contributed expertise in long term experimental platforms and agroecology. She specifically contributed to the writing of sections 2,7 and 8 and the overall editing of the review article. Adrian C. Newton contributed expertise in crop diversity, particularly variety mixtures and contributed to the writing of sections 4, 5 and 8 in addition to overall editing of the review article. Blair M. McKenzie contributed expertise in precision agriculture and controlled traffic and knowledge of long term experimental platforms in the tropics. He also contributed to the writing of sections 2,4 and 8 and to the overall editing of the review article. Paul D. Hallett contributed experitise on impacts of tillage on soil physical conditions and field phenotyping and to the writing of sections 3, 5 and 8, in addition to overall editing of the review article. Tracy A. Valentine contributed to overall conception of the article and formulating the individual contributions into a whole narrative. She specifically contributed expertise in field and controlled environment phenotyping and understanding of modelling at a range of scales, contributing to the writing of sections $1,2,3,6$ and 8 .

\section{Conflicts of Interest}

The authors declare no conflict of interests.

\section{References}

1. Lynch, J.P. Roots of the second green revolution. Aust. J. Bot. 2007, 55, 493-512.

2. Swaminathan, M.S. Can science and technology feed the world in 2025? Field Crops Res. 2007, 104, 3-9.

3. Tester, M.; Langridge, P. Breeding technologies to increase crop production in a changing world. Science 2010, 327, 818-822.

4. White, P.J.; George, T.S.; Gregory, P.J.; Bengough, A.G.; Hallett, P.D.; McKenzie, B.M. Matching roots to their environment. Ann. Bot. 2013, 112, 207-222. 
5. White, P.J.; George, T.S.; Dupuy, L.X.; Karley, A.J.; Valentine, T.A.; Wiesel, L.; Wishart, J. Root traits for infertile soils. Front. Plant Sci. 2013, 4, 193-193.

6. Pinheiro de Carvalho, M.A.A.; Bebeli, P.J.; Bettencourt, E.; Costa, G.; Dias, S.; dos Santos, T.M.M.; Slaski, J.J. Cereal landraces genetic resources in worldwide genebanks. A review. Agron. Sustain. Dev. 2013, 33, 177-203.

7. Monaco, M.K.; Stein, J.; Naithani, S.; Wei, S.; Dharmawardhana, P.; Kumari, S.; Amarasinghe, V.; Youens-Clark, K.; Thomason, J.; Preece, J.; et al. Gramene 2013: Comparative plant genomics resources. Nucleic Acids Res. 2014, 42, D1193-D1199.

8. Mujeeb-Kazi, A.; Kazi, A.G.; Dundas, I.; Rasheed, A.; Ogbonnaya, F.; Kishii, M.; Bonnett, D.; Wang, R.R.C.; Xu, S.; Chen, P.; et al. Genetic diversity for wheat improvement as a conduit to food security. Adv. Agron. 2013, 122, 179-257.

9. Chochois, V.; Vogel, J.P.; Watt, M. Application of brachypodium to the genetic improvement of wheat roots. J. Exp. Bot. 2012, 63, 3467-3474.

10. Gregory, P.J.; Atkinson, C.J.; Bengough, A.G.; Else, M.A.; Fernandez-Fernandez, F.; Harrison, R.J.; Schmidt, S. Contributions of roots and rootstocks to sustainable, intensified crop production. J. Exp. Bot. 2013, 64, 1209-1222.

11. Wurschum, T. Mapping QTL for agronomic traits in breeding populations. Theor. Appl. Genet. 2012, 125, 201-210.

12. Paulus, S.; Dupuis, J.; Mahlein, A.-K.; Kuhlmann, H. Surface feature based classification of plant organs from 3D laserscanned point clouds for plant phenotyping. BMC Bioinform. 2013, 14, doi:10.1186/1471-2105-14-238.

13. Mahlein, A.-K.; Oerke, E.-C.; Steiner, U.; Dehne, H.-W. Recent advances in sensing plant diseases for precision crop protection. Eur. J. Plant Pathol. 2012, 133, 197-209.

14. Mahlein, A.-K.; Steiner, U.; Hillnhuetter, C.; Dehne, H.-W.; Oerke, E.-C. Hyperspectral imaging for small-scale analysis of symptoms caused by different sugar beet diseases. Plant Methods 2012, 8, doi:10.1186/1746-4811-8-3.

15. Broadley, M.R.; White, P.J.; Hammond, J.P.; Zelko, I.; Lux, A. Zinc in plants. New Phytol. 2007, 173, 677-702.

16. Ismail, A.M.; Heuer, S.; Thomson, M.J.; Wissuwa, M. Genetic and genomic approaches to develop rice germplasm for problem soils. Plant Mol. Biol. 2007, 65, 547-570.

17. White, P.J.; Brown, P.H. Plant nutrition for sustainable development and global health. Ann. Bot. 2010, 105, 1073-1080.

18. Vonuexkull, H.R.; Mutert, E. Global extent, development and economic-impact of acid soils. Plant Soil 1995, 171, 1-15.

19. Sumner, M.E.; Noble, A.D. Soil Acidification: The World Story. In Handbook of Soil Acidity; Rengel, Z., Ed.; Marcel Dekker Inc.: New York, NY, USA, 2003; pp. 1-28.

20. White, P.J.; Broadley, M.R. Biofortification of crops with seven mineral elements often lacking in human diets-Iron, zinc, copper, calcium, magnesium, selenium and iodine. New Phytol. 2009, 182, 49-84.

21. Bennett, S.J.; Barrett-Lennard, E.G.; Colmer, T.D. Salinity and waterlogging as constraints to saltland pasture production: A review. Agric. Ecosyst. Environ. 2009, 129, 349-360. 
22. Munns, R.; Tester, M. Mechanisms of salinity tolerance. Annu. Rev. Plant Biol. 2008, 59, $651-681$.

23. White, P.J.G.; Greenwood, D.J. Properties and management of cationic elements for crop growth. In Russell's Soil Conditions and Plant Growth, 12th ed.; Gregory, P.J., Nortcliff, S., Eds.; Wiley-Blackwell: Oxford, UK, 2013.

24. Lynch, J.P. Root phenes for enhanced soil exploration and phosphorus acquisition: Tools for future crops. Plant Physiol. 2011, 156, 1041-1049.

25. Fageria, N.K.; Baligar, V.C.; Jones, C.A. Growth and Mineral Nutrition of Field Crops; CRC Press: Boca Raton, FL, USA, 2011.

26. Mueller, N.D.; Gerber, J.S.; Johnston, M.; Ray, D.K.; Ramankutty, N.; Foley, J.A. Closing yield gaps through nutrient and water management. Nature 2012, 490, 254-257.

27. Bengough, A.G.; Bransby, M.F.; Hans, J.; McKenna, S.J.; Roberts, T.J.; Valentine, T.A. Root responses to soil physical conditions; growth dynamics from field to cell. J. Exp. Bot. 2006, 57, $437-447$.

28. Valentine, T.A.; Hallett, P.D.; Binnie, K.; Young, M.W.; Squire, G.R.; Hawes, C.; Bengough, A.G. Soil strength and macropore volume limit root elongation rates in many UK agricultural soils. Ann. Bot. 2012, 110, 259-270.

29. Hallett, P.D; Bengough, A.G. Managing the soil physical environment for plants. In Russell's Soil Conditions and Plant Growth, 12th ed.; Gregory, P.J., Nortcliff, S., Eds.; Wiley-Blackwell: Oxford, UK, 2013.

30. Richards, R.A.; Watt, M.; Rebetzke, G.J. Physiological traits and cereal germplasm for sustainable agricultural systems. Euphytica 2007, 154, 409-425.

31. Jackson, M.B.; Colmer, T.D. Response and adaptation by plants to flooding stress-Preface. Ann. Bot. 2005, 96, 501-505.

32. Abdalla, M.; Osborne, B.; Lanigan, G.; Forristal, D.; Williams, M.; Smith, P.; Jones, M.B. Conservation tillage systems: A review of its consequences for greenhouse gas emissions. Soil Use Manag. 2013, 29, 199-209.

33. Farage, P.K.; Ardoe, J.; Olsson, L.; Rienzi, E.A.; Ball, A.S.; Pretty, J.N. The potential for soil carbon sequestration in three tropical dryland farming systems of Africa and Latin America: A modelling approach. Soil Tillage Res. 2007, 94, 457-472.

34. Llewellyn, R.S.; D'Emden, F.H.; Kuehne, G. Extensive use of no-tillage in grain growing regions of Australia. Field Crops Res. 2012, 132, 204-212.

35. McKenzie, B.M.; Bengough, A.G.; Hallett, P.D.; Thomas, W.T.B.; Forster, B.; McNicol, J.W. Deep rooting and drought screening of cereal crops: A novel field-based method and its application. Field Crops Res. 2009, 112, 165-171.

36. Watt, M.; Kirkegaard, J.A.; Rebetzke, G.J. A wheat genotype developed for rapid leaf growth copes well with the physical and biological constraints of unploughed soil. Funct. Plant Biol. 2005, 32, 695-706.

37. White, J.W.; Andrade-Sanchez, P.; Gore, M.A.; Bronson, K.F.; Coffelt, T.A.; Conley, M.M.; Feldmann, K.A.; French, A.N.; Heun, J.T.; Hunsaker, D.J.; et al. Field-based phenomics for plant genetics research. Field Crops Res. 2012, 133, 101-112. 
38. Staedler, Y.M.; Masson, D.; Schoenenberger, J. Plant tissues in 3D via X-ray tomography: Simple contrasting methods allow high resolution imaging. PLoS One 2013, 8, e 75295.

39. Shi, L.; Shi, T.X.; Broadley, M.R.; White, P.J.; Long, Y.; Meng, J.L.; Xu, F.S.; Hammond, J.P. High-throughput root phenotyping screens identify genetic loci associated with root architectural traits in brassica napus under contrasting phosphate availabilities. Ann. Bot. 2013, 112, 381-389.

40. Petersen, J.; Thomsen, I.K.; Mattsson, L.; Hansen, E.M.; Christensen, B.T. Crop response to sustained reductions in annual nitrogen fertilizer rates using long-term experiments as research platform. In Proceedings of NJF Seminar 407, Askov Experimental Station and Sandbjerg Estate, Jutland, Denmark, 16-18 June 2008; pp. 36-39.

41. Horn, R. Division s-1-Soil physics - Time dependence of soil mechanical properties and pore functions for arable soils. Soil Sci. Soc. Am. J. 2004, 68, 1131-1137.

42. Powlson, D.S.; Poulton, P.R.; Macdonald, A.J. Long-term experiments as unique resources for research on local and global carbon cycling. In Proceedings of NJF Seminar 407, Askov Experimental Station and Sandbjerg Estate, Jutland, Denmark, 16-18 June 2008; pp. 20-23.

43. Johnston, A.E.; Poulton, P.R.; Coleman, K. Soil organic matter: Its importance in sustainable agriculture and carbon dioxide fluxes. Adv. Agron. 2009, 101, 1-57.

44. Hofmann, A.; Heim, A.; Christensen, B.T.; Gioacchini, P.; Miltner, A.; Gehre, M.; Schmidt, M.W.I. Tracking the fate of lignin in 13C-labelled arable soils. In Proceedings of NJF Seminar 407, Askov Experimental Station and Sandbjerg Estate, Jutland, Denmark, 16-18 June 2008; pp. 28-31.

45. Peterson, M.J. Introduction to the biological monitoring and abatement program. Environ. Manag. 2011, 47, 1005-1009.

46. Goulding, K. Long-term research in the UK-Lessons learned from the rothamsted classical experiments. Kungl. Skogs Lantbr. Tidskr. 2007, 146, 8-12.

47. Korschens, M. The importance of long-term field experiments for soil science and environmental research-A review. Plant Soil Environ. 2006, 52, 1-8.

48. Rasmussen, P.E.; Goulding, K.W.T.; Brown, J.R.; Grace, P.R.; Janzen, H.H.; Korschens, M. Agroecosystem-Long-term agroecosystem experiments: Assessing agricultural sustainability and global change. Science 1998, 282, 893-896.

49. Franko, U.; Schramm, G.; Rodionova, V.; Korschens, M.; Smith, P.; Coleman, K.; Romanenkov, V.; Shevtsova, L. Eurosomnet-A database for long-term experiments on soil organic matter in Europe. Comput. Electron. Agric. 2002, 33, 233-239.

50. LTSE Website, Global Inventory of Long-Term Soil-Ecosystem Experiments. Available online: http://nicholas.duke.edu/ltse/ (accessed on 4 February 2014).

51. Petersen, J.; Mattsson, L.; Riley, H.; Salo, T.; Thorvaldsson, G.; Christensen, B.T. An inventory of nordic long continued agricultural soil experiments. In Long-Term Field Experiments - A Unique Research Platform, Proceedings of NJF Seminar 407, Askov Experimental Station and Sandbjerg Estate, Denmark, 16-18 June 2008; pp. 76-79.

52. Hyvonen, R.; Agren, G.I.; Andren, O. Modelling long-term: Carbon and nitrogen dynamics in an arable soil receiving organic matter. Ecol. Appl. 1996, 6, 1345-1354.

53. Powlson, D.S.; Glendining, M.J.; Coleman, K.; Whitmore, A.P. Implications for soil properties of removing cereal straw: Results from long-term studies. Agron. J. 2011, 103, 279-287. 
54. Paul, E.A.; Follett, R.F.; Leavitt, S.W.; Halvorson, A.; Peterson, G.A.; Lyon, D.J. Radiocarbon dating for determination of soil organic matter pool sizes and dynamics. Soil Sci. Soc. Am. J. 1997, 61, 1058-1067.

55. Smith, P.; Smith, J.U.; Powlson, D.S.; McGill, W.B.; Arah, J.R.M.; Chertov, O.G.; Coleman, K.; Franko, U.; Frolking, S.; Jenkinson, D.S.; et al. A comparison of the performance of nine soil organic matter models using datasets from seven long-term experiments. Geoderma 1997, 81, 153-225.

56. Andren, O.; Katterer, T. Icbm: The introductory carbon balance model for exploration of soil carbon balances. Ecol. Appl. 1997, 7, 1226-1236.

57. Gerzabek, M.H. Soil organic matter research using long-term experiments. Kungl. Skogs Lantbr. Tidskr. 2007, 146, 22-29.

58. Sun, B.; Hallett, P.D.; Caul, S.; Daniell, T.J.; Hopkins, D.W. Distribution of soil carbon and microbial biomass in arable soils under different tillage regimes. Plant Soil 2011, 338, 17-25.

59. Katterer, T.; Andren, O. Long-term agricultural field experiments in northern Europe: Analysis of the influence of management on soil carbon stocks using the ICBM model. Agric. Ecosyst. Environ. 1999, 75, 145-146.

60. Petersen, J.; Mattsson, L.; Riley, H.; Salo, T.; Thorvaldsson, G.; Christensen, B.T. Long continued agricultural soil experiments: A nordic research platform-An overview. In Proceedings of NJF Seminar 407, Askov Experimental Station and Sandbjerg Estate, Jutland, Denmark, 16-18 June 2008.

61. Riley, H. Long-term fertilizer trials on loam soil at moystad, south-eastern Norway: Crop yields, nutrient balances and soil chemical analyses from 1983 to 2003. Acta Agric. Scand. Sect. B Soil Plant Sci. 2007, 57, 140-154.

62. Mazzoncini, M.; di Bene, C.; Coli, A.; Risaliti, R.; Bonari, E. Long-term tillage and nitrogen fertilisation effects on maize yield and soil quality under rainfed mediterranean conditions: A critical perspective. DJF Rapp. Markbrug 2008, 7, 13-16.

63. Saarela, I. Changes of yield responses and soil test values in finnish soils in relation to cumulative phosphorus and potassium balances. DJF Rapp. Markbrug 2008, 4, 52-55.

64. Jaakkola, A.; Yli-Halla, M. Thirty years of growing cereal without $\mathrm{P}$ and $\mathrm{K}$ fertilization. DJF Rapp. Markbrug 2008, 4, 17-19.

65. Magid, J.; Jensen, L.S. The crucial facility: A long-term field trial with urban fertilizers-Is recycling of nutrients from urban areas to peri-urban areas detrimental to the environment or the production system integrity? DJF Rapp. Markbrug 2008, 7, 11-12.

66. Lessons Learned from Long-Term Soil Fertility Management Experiments in Africa; Bationo, A., Waswa, B., Kihara, J., Adolwa, I., Vanlauwe, B., Saidou, K., Eds.; Springer: Dordrecht, Netherlands, 2012; p. 204.

67. Hawes, C.; George, T.; Iannetta, P.P.M.; James, E.K.; Karley, A.J.; McKenzie, B.M.; McNichol, J.W.; Squire, G.R.; Valentine, T.; Young, M. A whole-systems approach for designing sustainable cropping systems in northern Europe. Int. J. Agric. Sustain. 2014, in press. 
68. Griffith, B.A.H.; Hawkins, J.M.B.; Orr, R.J.; Blackwell, M.S.A.; Murray, P.J. The north wyke farm platform: Methodologies used in the remote sensing of the quantity and quality of drainage water. In Proceedings of the 22nd International Grasslands Congress, Sydney, Australia, 15-19 September 2013.

69. Hatch, D.; Murray, P.; Orr, R.; Griffith, B. The North Wyke Farm Platform: A UK national capability for agri-environmental research. Asp. Appl. Biol. 2011, 115-118.

70. Chabbi, A.; Lemaire, G. Long term agro-ecosystem platforms for assessing biogeochemical cycles, environmental fluxes and biodiversity. In Proceedings of NJF Seminar 407. Askov Experimental Station and Sandbjerg Estate, Jutland, Denmark, 16-18 June 2008; pp. 73-75.

71. Firbank, L.G.; Heard, M.S.; Woiwod, I.P.; Hawes, C.; Haughton, A.J.; Champion, G.T.; Scott, R.J.; Hill, M.O.; Dewar, A.M.; Squire, G.R.; et al. An introduction to the farm-scale evaluations of genetically modified herbicide-tolerant crops. J. Appl. Ecol. 2003, 40, 2-16.

72. Perry, J.N.; Rothery, P.; Clark, S.J.; Heard, M.S.; Hawes, C. Design, analysis and statistical power of the farm-scale evaluations of genetically modified herbicide-tolerant crops. J. Appl. Ecol. 2003, 40, 17-31.

73. Hawes, C.; Squire, G.R.; Hallett, P.D.; Watson, C.A.; Young, M. Arable plant communities as indicators of farming practice. Agric. Ecosyst. Environ. 2010, 138, 17-26.

74. Tamis, W.L.M.; van den Brink, W.J. Conventional, integrated and organic winter wheat production in the Netherlands in the period 1993-1997. Agric. Ecosyst. Environ. 1999, 76, 47-59.

75. Rutter, M.T.; Fenster, C.B. Testing for adaptation to climate in arabidopsis thaliana: A calibrated common garden approach. Ann. Bot. 2007, 99, 529-536.

76. Oleksyn, J.; Modrzynski, J.; Tjoelker, M.G.; Zytkowiak, R.; Reich, P.B.; Karolewski, P. Growth and physiology of picea abies populations from elevational transects: Common garden evidence for altitudinal ecotypes and cold adaptation. Funct. Ecol. 1998, 12, 573-590.

77. Tracy, S.R.; Roberts, J.A.; Black, C.R.; McNeill, A.; Davidson, R.; Mooney, S.J. The X-factor: Visualizing undisturbed root architecture in soils using X-ray computed tomography. J. Exp. Bot. 2010, 61, 311-313.

78. Clark, R.T.; MacCurdy, R.B.; Jung, J.K.; Shaff, J.E.; McCouch, S.R.; Aneshansley, D.J.; Kochian, L.V. Three-dimensional root phenotyping with a novel imaging and software platform. Plant Physiol. 2011, 156, 455-465.

79. De Dorlodot, S.; Bertin, P.; Baret, P.; Draye, X. Scaling up quantitative phenotyping of root system architecture using a combination of aeroponics and image analysis. In Proceedings of "Roots and the Soil Environment II", Nottingham, UK, April 2005; pp. 41-54.

80. Downie, H.; Holden, N.; Otten, W.; Spiers, A.J.; Valentine, T.A.; Dupuy, L.X. Transparent soil for imaging the rhizosphere. PLoS One 2012, 7, e44276.

81. Yang, W.; Duan, L.; Chen, G.; Xiong, L.; Liu, Q. Plant phenomics and high-throughput phenotyping: Accelerating rice functional genomics using multidisciplinary technologies. Curr. Opin. Plant Biol. 2013, 16, 180-187.

82. Karley, A.J.; Valentine, T.A.; Squire, G.R. Dwarf alleles differentially affect barley root traits influencing nitrogen acquisition under low nutrient supply. J. Exp. Bot. 2011, 62, 3917-3927. 
83. Wishart, J.; George, T.S.; Brown, L.K.; Ramsay, G.; Bradshaw, J.E.; White, P.J.; Gregory, P.J. Measuring variation in potato roots in both field and glasshouse: The search for useful yield predictors and a simple screen for root traits. Plant Soil 2013, 368, 231-249.

84. Zadoks, J.C.; Chang, T.T.; Konzak, C.F. A decimal code for the growth stages of cereals. Weed Res. 1974, 14, 415-421.

85. Tajima, R.; Kato, Y. Comparison of threshold algorithms for automatic image processing of rice roots using freeware ImageJ. Field Crops Res. 2011, 121, 460-463.

86. Maloof, J.N.; Nozue, K.; Mumbach, M.R.; Palmer, C.M. LeafJ: An ImageJ plugin for semi-automated leaf shape measurement. J. Vis. Exp. 2013, 71, doi:10.3791/50028.

87. Trachsel, S.; Kaeppler, S.M.; Brown, K.M.; Lynch, J.P. Shovelomics: High throughput phenotyping of maize (Zea mays L.) root architecture in the field. Plant Soil 2011, 341, 75-87.

88. Haling, R.E.; Simpson, R.J.; Culvenor, R.A.; Lambers, H.; Richardson, A.E. Field application of a DNA-based assay to the measurement of roots of perennial grasses. Plant Soil 2012, 358, 176-192.

89. Haling, R.E.; Simpson, R.J.; McKay, A.C.; Hartley, D.; Lambers, H.; Ophel-Keller, K.; Wiebkin, S.; Herdina; Riley, I.T.; Richardson, A.E. Direct measurement of roots in soil for single and mixed species using a quantitative DNA-based method. Plant Soil 2011, 348, 123-137.

90. Huang, C.Y.; Kuchel, H.; Edwards, J.; Hall, S.; Parent, B.; Eckermann, P.; Herdina; Hartley, D.M.; Langridge, P.; McKay, A.C. A DNA-based method for studying root responses to drought in field-grown wheat genotypes. Sci. Rep. 2013, 3, 3194.

91. Roessner, U.; Willmitzer, L.; Fernie, A.R. High-resolution metabolic phenotyping of genetically and environmentally diverse potato tuber systems. Identification of phenocopies. Plant Physiol. 2001, 127, 749-764.

92. Roessner, U.; Luedemann, A.; Brust, D.; Fiehn, O.; Linke, T.; Willmitzer, L.; Fernie, A.R. Metabolic profiling allows comprehensive phenotyping of genetically or environmentally modified plant systems. Plant Cell 2001, 13, 11-29.

93. Roessner, U.; Willmitzer, L.; Fernie, A.R. Metabolic profiling and biochemical phenotyping of plant systems. Plant Cell Rep. 2002, 21, 189-196.

94. Golzarian, M.R.; Frick, R.A. Classification of images of wheat, ryegrass and brome grass species at early growth stages using principal component analysis. Plant Methods 2011, 7, 28.

95. Al-Tam, F.M.; Adam, H.; Anjos, A.D.; Lorieux, M.; Larmande, P.; Ghesquiere, A.; Jouannic, S.; Shahbazkia, H.R. P-TRAP: A Panicle Trait Phenotyping tool. BMC Plant Biol. 2013, 13, 122.

96. Rousseau, C.; Belin, E.; Bove, E.; Rousseau, D.; Fabre, F.; Berruyer, R.; Guillaumes, J.; Manceau, C.; Jacques, M.-A.; Boureau, T. High throughput quantitative phenotyping of plant resistance using chlorophyll fluorescence image analysis. Plant Methods 2013, 9, 17.

97. Mooney, S.J.; Pridmore, T.P.; Helliwell, J.; Bennett, M.J. Developing X-ray computed tomography to non-invasively image 3-D root systems architecture in soil. Plant Soil 2012, 352, 1-22.

98. Keyes, S.D.; Daly, K.R.; Gostling, N.J.; Jones, D.L.; Talboys, P.; Pinzer, B.R.; Boardman, R.; Sinclair, I.; Marchant, A.; Roose, T. High resolution synchrotron imaging of wheat root hairs growing in soil and image based modelling of phosphate uptake. New Phytol. 2013, 198, 1023-1029. 
99. Mairhofer, S.; Zappala, S.; Tracy, S.; Sturrock, C.; Bennett, M.J.; Mooney, S.J.; Pridmore, T.P. Recovering complete plant root system architectures from soil via X-ray $\mu$-Computed Tomography. Plant Methods 2013, 9, 8 .

100. Miguel Costa, J.; Grant, O.M.; Manuela Chaves, M. Thermography to explore plant-environment interactions. J. Exp. Bot. 2013, 64, 3937-3949.

101. Guo, W.; Rage, U.K.; Ninomiya, S. Illumination invariant segmentation of vegetation for time series wheat images based on decision tree model. Comput. Electron. Agric. 2013, 96, 58-66.

102. Murchie, E.H.; Lawson, T. Chlorophyll fluorescence analysis: A guide to good practice and understanding some new applications. J. Exp. Bot. 2013, 64, 3983-3998.

103. Prashar, A.; Yildiz, J.; McNicol, J.W.; Bryan, G.J.; Jones, H.G. Infra-red thermography for high throughput field phenotyping in Solanum tuberosum. PLoS One 2013, 8, e65816.

104. Jones, H.G.; Serraj, R.; Loveys, B.R.; Xiong, L.; Wheaton, A.; Price, A.H. Thermal infrared imaging of crop canopies for the remote diagnosis and quantification of plant responses to water stress in the field. Funct. Plant Biol. 2009, 36, 978-989.

105. Hackl, H.; Baresel, J.P.; Mistele, B.; Hu, Y.; Schmidhalter, U. A comparison of plant temperatures as measured by thermal imaging and infrared thermometry. J. Agron. Crop Sci. 2012, 198, 415-429.

106. Gutierrez, M.; Reynolds, M.P.; Klatt, A.R. Association of water spectral indices with plant and soil water relations in contrasting wheat genotypes. J. Exp. Bot. 2010, 61, 3291-3303.

107. Munns, R.; James, R.A.; Sirault, X.R.R.; Furbank, R.T.; Jones, H.G. New phenotyping methods for screening wheat and barley for beneficial responses to water deficit. J. Exp. Bot. 2010, 61, 3499-3507.

108. Thoren, D.; Schmidhalter, U. Nitrogen status and biomass determination of oilseed rape by laser-induced chlorophyll fluorescence. Eur. J. Agron. 2009, 30, 238-242.

109. Thoren, D.; Thoren, P.; Schmidhalter, U. Influence of ambient light and temperature on laser-induced chlorophyll fluorescence measurements. Eur. J. Agron. 2010, 32, 169-176.

110. Dietrich, R.C.; Bengough, A.G.; Jones, H.G.; White, P.J. A new physical interpretation of plant root capacitance. J. Exp. Bot. 2012, 63, 6149-6159.

111. Chapuis, R.; Delluc, C.; Debeuf, R.; Tardieu, F.; Welcker, C. Resiliences to water deficit in a phenotyping platform and in the field: How related are they in maize? Eur. J. Agron. 2012, 42, 59-67.

112. Dietrich, R.C.; Bengough, A.G.; Jones, H.G.; White, P.J. Can root electrical capacitance be used to predict root mass in soil? Ann. Bot. 2013, 112, 457-464.

113. D'Andrea, K.E.; Otegui, M.E.; Cirilo, A.G.; Eyherabide, G.H. Ecophysiological traits in maize hybrids and their parental inbred lines: Phenotyping of responses to contrasting nitrogen supply levels. Field Crops Res. 2009, 114, 147-158.

114. Montes, J.M.; Technow, F.; Dhillon, B.S.; Mauch, F.; Melchinger, A.E. High-throughput non-destructive biomass determination during early plant development in maize under field conditions. Field Crops Res. 2011, 121, 268-273.

115. Busemeyer, L.; Mentrup, D.; Moeller, K.; Wunder, E.; Alheit, K.; Hahn, V.; Maurer, H.P.; Reif, J.C.; Wuerschum, T.; Mueller, J.; et al. Breedvision-A multi-sensor platform for non-destructive field-based phenotyping in plant breeding. Sensors 2013, 13, 2830-2847. 
116. Granier, C.; Tardieu, F. Multi-scale phenotyping of leaf expansion in response to environmental changes: The whole is more than the sum of parts. Plant Cell Environ. 2009, 32, 1175-1184.

117. Rebetzke, G.J.; Chenu, K.; Biddulph, B.; Moeller, C.; Deery, D.M.; Rattey, A.R.; Bennett, D.; Barrett-Lennard, E.G.; Mayer, J.E. A multisite managed environment facility for targeted trait and germplasm phenotyping. Funct. Plant Biol. 2013, 40, 1-13.

118. Paproki, A.; Sirault, X.; Berry, S.; Furbank, R.; Fripp, J. A novel mesh processing based technique for 3D plant analysis. BMC Plant Biol. 2012, 12, doi:10.1186/1471-2229-12-63.

119. Vankadavath, R.N.; Hussain, A.J.; Bodanapu, R.; Kharshiing, E.; Basha, P.O.; Gupta, S.; Sreelakshmi, Y.; Sharma, R. Computer aided data acquisition tool for high-throughput phenotyping of plant populations. Plant Methods 2009, 5, 18.

120. Hallett, P.; Mooney, S.; Whalley, R. Soil physics: New approaches and emerging challenges introduction. Eur. J. Soil Sci. 2013, 64, 277-278.

121. Kirkegaard, J.A.; Lilley, J.M. Root penetration rate-A benchmark to identify soil and plant limitations to rooting depth in wheat. Aust. J. Exp. Agric. 2007, 47, 590-602.

122. George, T.S.; Brown, L.K.; Newton, A.C.; Hallett, P.D.; Sun, B.H.; Thomas, W.T.B.; White, P.J. Impact of soil tillage on the robustness of the genetic component of variation in phosphorus (P) use efficiency in barley (Hordeum vulgare L.). Plant Soil 2011, 339, 113-123.

123. Ball, B.C.; Douglas, J.T. A simple procedure for assessing soil structural, rooting and surface conditions. Soil Use Manag. 2003, 19, 50-56.

124. Moebius, B.N.; van Es, H.M.; Schindelbeck, R.R.; Idowu, O.J.; Clune, D.J.; Thies, J.E. Evaluation of laboratory-measured soil properties as indicators of soil physical quality. Soil Sci. 2007, 172, 895-912.

125. Silva, G.L.; Lima, H.V.; Campanha, M.M.; Gilkes, R.J.; Oliveira, T.S. Soil physical quality of luvisols under agroforestry, natural vegetation and conventional crop management systems in the Brazilian semi-arid region. Geoderma 2011, 167-168, 61-70.

126. Dexter, A.R. Soil physical quality-Part I. Theory, effects of soil texture, density, and organic matter, and effects on root growth. Geoderma 2004, 120, 201-214.

127. Czyz, E.A. Effects of traffic on soil aeration, bulk density and growth of spring barley. Soil Tillage Res. 2004, 79, 153-166.

128. Bengough, A.G.; McKenzie, B.M.; Hallett, P.D.; Valentine, T.A. Root elongation, water stress, and mechanical impedance: A review of limiting stresses and beneficial root tip traits. J. Exp. Bot. 2011, 62, 59-68.

129. DaSilva, A.P.; Kay, B.D. The sensitivity of shoot growth of corn to the least limiting water range of soils. Plant Soil 1996, 184, 323-329.

130. Ehlers, W.; Kopke, U.; Hesse, F.; Bohm, W. Penetration resistance and root-growth of oats in tilled and untilled loess soil. Soil Tillage Res 1983, 3, 261-275.

131. White, R.G.; Kirkegaard, J.A. The distribution and abundance of wheat roots in a dense, structured subsoil-Implications for water uptake. Plant Cell Environ. 2010, 33, 133-148.

132. Reynolds, W.D.; Drury, C.F.; Tan, C.S.; Fox, C.A.; Yang, X.M. Use of indicators and pore volume-function characteristics to quantify soil physical quality. Geoderma 2009, 152, 252-263.

133. Mueller, L.; Kay, B.D.; Hu, C.; Li, Y.; Schindler, U.; Behrendt, A.; Shepherd, T.G.; Ball, B.C. Visual assessment of soil structure: Evaluation of methodologies on sites in Canada, China and 
Germany part I: Comparing visual methods and linking them with soil physical data and grain yield of cereals. Soil Tillage Res. 2009, 103, 178-187.

134. Ball, B.C.; Munkholm, L.J.; Batey, T. Applications of visual soil evaluation. Soil Tillage Res. 2013, 127, 1-2.

135. Aitkenhead, M.J.; Coull, M.C.; Donnelly, D.; Hastings, E.J. Innovations in environmental monitoring using mobile technology-A review. Int. J. Interact. Mob. Technol. 2014, 8, 50-58.

136. Mairura, F.S.; Mugendi, D.N.; Mwanje, J.I.; Rarnisch, J.J.; Mbugua, P.K.; Chianu, J.N. Integrating scientific and fanners' evaluation of soil quality indicators in central Kenya. Geoderma 2007, 139, 134-143.

137. Fernandez-Ugalde, O.; Virto, I.; Bescansa, P.; Imaz, M.J.; Enrique, A.; Karlen, D.L. No-tillage improvement of soil physical quality in calcareous, degradation-prone, semiarid soils. Soil Tillage Res. 2009, 106, 29-35.

138. Celeste Miretti, M.; Imhoff, S.; da Silva, A.P.; Lavado, R. Soil structure degradation in patches of alfalfa fields. Sci. Agric. 2010, 67, 604-610.

139. Connor, D.J. Organic agriculture cannot feed the world. Field Crops Res. 2008, 106, 187-190.

140. De Ponti, T.; Rijk, B.; van Ittersum, M.K. The crop yield gap between organic and conventional agriculture. Agric. Syst. 2012, 108, 1-9.

141. Ball, B.C.; Crawford, C.E. Mechanical weeding effects on soil structure under field carrots (Daucus carota L.) and beans (Vicia faba L.). Soil Use Manag. 2009, 25, 303-310.

142. Loeschenberger, F.; Fleck, A.; Grausgruber, H.; Hetzendorfer, H.; Hof, G.; Lafferty, J.; Marn, M.; Neumayer, A.; Pfaffinger, G.; Birschitzky, J. Breeding for organic agriculture: The example of winter wheat in Austria. Euphytica 2008, 163, 469-480.

143. Wolfe, M.S.; Baresel, J.P.; Desclaux, D.; Goldringer, I.; Hoad, S.; Kovacs, G.; Loeschenberger, F.; Miedaner, T.; Ostergard, H.; van Bueren, E.T.L. Developments in breeding cereals for organic agriculture. Euphytica 2008, 163, 323-346.

144. Casler, M.; Riday, H.; Undersander, D. Organic vs. Conventional fodder crops in the USA: A challenge for breeders? In Proceedings of the EUCARPIA Fodder Crops Meetings, Copenhagen, Denmark, 19-23 August 2007; pp. 17-23.

145. Boller, B.; Tanner, P.; Schubiger, F.X. Breeding forage grasses for organic conditions. Euphytica 2008, 163, 459-467.

146. Houlbrooke, D.J.; Paton, R.J.; Littlejohn, R.P.; Morton, J.D. Land-use intensification in New Zealand: Effects on soil properties and pasture production. J. Agric. Sci. 2011, 149, 337-349.

147. Beutler, A.N.; Centurion, J.F.; da Silva, A.P.; Pessoa da Cruz Centurion, M.A.; Leonel, C.L.; da Freddi, O.S. Soil compaction by machine traffic and least limiting water range related to soybean yield. Pesqui. Agropecu. Bras. 2008, 43, 1591-1600.

148. Van Bueren, E.T.L.; Jones, S.S.; Tamm, L.; Murphy, K.M.; Myers, J.R.; Leifert, C.; Messmer, M.M. The need to breed crop varieties suitable for organic farming, using wheat, tomato and broccoli as examples: A review. NJAS-Wagening. J. Life Sci. 2011, 58, 193-205.

149. Wojciechowski, T.; Gooding, M.J.; Ramsay, L.; Gregory, P.J. The effects of dwarfing genes on seedling root growth of wheat. J. Exp. Bot. 2009, 60, 2565-2573. 
150. Lueck, L.; Schmidt, C.S.; Cooper, J.M.; Hall, C.M.; Shotton, P.N.; Leifert, C. Effect of organic, low-input and conventional production systems on yield and quality of winter wheat. In Delivering Sustainability within Profitable Farming Systems - Is It Possible? Andrews, M., Turley, D., Cummings, S., Dale, M.F.B., Rowlinson, P., Eds.; Association of Applied Biologists: Warwickshire, UK, 2006; pp. 135-140.

151. Dawson, J.C.; Huggins, D.R.; Jones, S.S. Characterizing nitrogen use efficiency in natural and agricultural ecosystems to improve the performance of cereal crops in low-input and organic agricultural systems. Field Crops Res. 2008, 107, 89-101.

152. Hoad, S.; Topp, C.; Davies, K. Selection of cereals for weed suppression in organic agriculture: A method based on cultivar sensitivity to weed growth. Euphytica 2008, 163, 355-366.

153. Cooper, J.M.; Schmidt, C.S.; Wilkinson, A.; Lueck, L.; Hall, C.M.; Shotton, P.N.; Leifert, C. Effect of organic, "low-input" and conventional production systems on disease incidence and severity in winter wheat. Asp. Appl. Biol. 2006, 80, 121-126.

154. Makepeace, J.C.; Oxley, S.J.P.; Havis, N.D.; Hackett, R.; Burke, J.I.; Brown, J.K.M. Associations between fungal and abiotic leaf spotting and the presence of mlo alleles in barley. Plant Pathol. 2007, 56, 934-942.

155. Simon, M.R.; Worland, A.J.; Struik, P.C. Influence of plant height and heading date on the expression of the resistance to septoria tritici blotch in near isogenic lines of wheat. Crop Sci. 2004, 44, 2078-2085.

156. Klahr, A.; Zimmermann, G.; Wenzel, G.; Mohler, V. Effects of environment, disease progress, plant height and heading date on the detection of QTLs for resistance to fusarium head blight in an european winter wheat cross. Euphytica 2007, 154, 17-28.

157. Flintham, J.E.; Gale, M.D. The tom thumb dwarfing gene Rht3 in wheat. 2. Effects on height, yield and grain quality. Theor. Appl. Genet. 1983, 66, 249-256.

158. Beutler, A.N.; Centurion, J.F.; Mengatto, L.H.; Mengatto, L.H.; Alves, J.B.; Cardoso Wagner, G.P. Impact of machine traffic on soil physical quality and corn yield in a kandiustalf. Acta Sci. Agron. 2009, 31, 359-364.

159. Van Bueren, E.T.L.; Struik, P.C.; Jacobsen, E. Ecological concepts in organic farming and their consequences for an organic crop ideotype. Neth. J. Agric. Sci. 2002, 50, 1-26.

160. Cassman, K.G. Ecological intensification of cereal production systems: Yield potential, soil quality, and precision agriculture. Proc. Natl. Acad. Sci. USA 1999, 96, 5952-5959.

161. Dobermann, A.; Cassman, K.G. Plant nutrient management for enhanced productivity in intensive grain production systems of the United States and Asia. Plant Soil 2002, 247, 153-175.

162. Rossel, R.A.V.; McBratney, A.B. Laboratory evaluation of a proximal sensing technique for simultaneous measurement of soil clay and water content. Geoderma 1998, 85, 19-39.

163. Van Alphen, B.J.; Stoorvogel, J.J. A functional approach to soil characterization in support of precision agriculture. Soil Sci. Soc. Am. J. 2000, 64, 1706-1713.

164. Horn, R.; Fleige, H. Risk assessment of subsoil compaction for arable soils in Northwest Germany at farm scale. Soil Tillage Res. 2009, 102, 201-208.

165. Alakukku, L.; Weisskopf, P.; Chamen, W.C.T.; Tijink, F.G.J.; van der Linden, J.P.; Pires, S.; Sommer, C.; Spoor, G. Prevention strategies for field traffic-induced subsoil compaction: A review part 1. Machine/soil interactions. Soil Tillage Res. 2003, 73, 145-160. 
166. Holpp, M.; Kroulik, M.; Kviv, Z.; Anken, T.; Sauter, M.; Hensel, O. Large-scale field evaluation of driving performance and ergonomic effects of satellite-based guidance systems. Biosyst. Eng. 2013, 116, 190-197.

167. Kviv, Z.; Kroulik, M.; Chyba, J. Machinery guidance systems analysis concerning pass-to-pass accuracy as a toll for efficient plant production in fields and for soil damage reduction. Plant Soil Environ. 2014, 60, 36-42.

168. Betteridge, K.; Schnug, E.; Haneklaus, S. Will site specific nutrient management live up to expectation? Landbauforsch. Volkenrode 2008, 58, 283-293.

169. Haboudane, D.; Miller, J.R.; Pattery, E.; Zarco-Tejada, P.J.; Strachan, I.B. Hyperspectral vegetation indices and novel algorithms for predicting green LAI of crop canopies: Modeling and validation in the context of precision agriculture. Remote Sens. Environ. 2004, 90, 337-352.

170. Gasso, V.; Sorensen, C.A.G.; Oudshoorn, F.W.; Green, O. Controlled traffic farming: A review of the environmental impacts. Eur. J. Agron. 2013, 48, 66-73.

171. Newton, A.C.; Guy, D.C. Scale and spatial structure effects on the outcome of barley cultivar mixture trials for disease control. Field Crops Res. 2011, 123, 74-79.

172. Creissen, H.E.; Jorgensen, T.H.; Brown, J.K.M. Stabilization of yield in plant genotype mixtures through compensation rather than complementation. Ann. Bot. 2013, 112, 1439-1447.

173. Newton, A.C.; Guy, D.C.; Bengough, A.G.; Gordon, D.C.; McKenzie, B.M.; Sun, B.; Valentine, T.A.; Hallett, P.D. Soil tillage effects on the efficacy of cultivars and their mixtures in winter barley. Field Crops Res. 2012, 128, 91-100.

174. Locke, M.A.; Zablotowicz, R.M.; Steinriede, R.W.; Testa, S.; Reddy, K.N. Conservation management in cotton production: Long-term soil biological, chemical, and physical changes. Soil Sci. Soc. Am. J. 2013, 77, 974-984.

175. Vandenkoornhuyse, P.; Ridgway, K.P.; Watson, I.J.; Fitter, A.H.; Young, J.P.W. Co-existing grass species have distinctive arbuscular mycorrhizal communities. Mol. Ecol. 2003, 12, 3085-3095.

176. Skiba, M.W.; George, T.S.; Baggs, E.M.; Daniell, T.J. Plant influence on nitrification. Biochem. Soc. Trans. 2011, 39, 275-278.

177. Brooker, R.W.; Bennett, A.E.; Cong, W.-F.; Daniel, T.J.; George, T.S.; Hawes, C.; Iannetta, P.P.M.; Jones, H.G.; Karley, A.J.; Li, H.; et al. Improving intercropping: A synthesis of research in agronomy, plant physiology and ecology. New Phytol. 2014, in press.

178. Trichard, A.; Alignier, A.; Chauvel, B.; Petit, S. Identification of weed community traits response to conservation agriculture. Agric. Ecosyst. Environ. 2013, 179, 179-186.

179. Diacono, M.; Montemurro, F. Long-term effects of organic amendments on soil fertility. A review. Agron. Sustain. Dev. 2010, 30, 401-422.

180. Amato, G.; Ruisi, P.; Frenda, A.S.; di Miceli, G.; Saia, S.; Plaia, A.; Giambalvo, D. Long-term tillage and crop sequence effects on wheat grain yield and quality. Agron. J. 2013, 105, 1317-1327.

181. Arvidsson, J.; Etana, A.; Rydberg, T. Crop yield in swedish experiments with shallow tillage and no-tillage 1983-2012. Eur. J. Agron. 2014, 52 Pt B, 307-315.

182. Murphy, K.; Jones, S.S. Genetic assessment of the role of breeding wheat for organic systems. 2007, 12, 217-222. 
183. Reid, T.A.; Yang, R.-C.; Salmon, D.F.; Spaner, D. Should spring wheat breeding for organically managed systems be conducted on organically managed land? Euphytica 2009, 169, 239-252.

184. Wu, L.; McGechan, M.B.; McRoberts, N.; Baddeley, J.A.; Watson, C.A. Spacsys: Integration of a 3D root architecture component to carbon, nitrogen and water cycling-model description. Ecol. Model. 2007, 200, 343-359.

185. Fang, S.; Yan, X.; Liao, H. 3D reconstruction and dynamic modeling of root architecture in situ and its application to crop phosphorus research. Plant J. 2009, 60, 1096-1108.

186. El-Sharkawy, M.A. Overview: Early history of crop growth and photosynthesis modeling. Biosystems 2011, 103, 205-211.

187. Yin, X.; Struik, P.C. Modelling the crop: From system dynamics to systems biology. J. Exp. Bot. 2010, 61, 2171-2183.

188. Brisson, N.; Gary, C.; Justes, E.; Roche, R.; Mary, B.; Ripoche, D.; Zimmer, D.; Sierra, J.; Bertuzzi, P.; Burger, P.; et al. An overview of the crop model stics. Eur. J. Agron. 2003, 18, 309-332.

189. Hammer, G.L.; van Oosterom, E.; McLean, G.; Chapman, S.C.; Broad, I.; Harland, P.; Muchow, R.C. Adapting apsim to model the physiology and genetics of complex adaptive traits in field crops. J. Exp. Bot. 2010, 61, 2185-2202.

190. Jones, J.W.; Hoogenboom, G.; Porter, C.H.; Boote, K.J.; Batchelor, W.D.; Hunt, L.A.; Wilkens, P.W.; Singh, U.; Gijsman, A.J.; Ritchie, J.T. The dssat cropping system model. Eur. J. Agron. 2003, 18, 235-265.

191. Keating, B.A.; Carberry, P.S.; Hammer, G.L.; Probert, M.E.; Robertson, M.J.; Holzworth, D.; Huth, N.I.; Hargreaves, J.N.G.; Meinke, H.; Hochman, Z.; et al. An overview of apsim, a model designed for farming systems simulation. Eur. J. Agron. 2003, 18, 267-288.

192. Stockle, C.O.; Donatelli, M.; Nelson, R. Cropsyst, a cropping systems simulation model. Eur. J. Agron. 2003, 18, 289-307.

193. Dunbabin, V.M.; Diggle, A.J.; Rengel, Z.; van Hugten, R. Modelling the interactions between water and nutrient uptake and root growth. Plant Soil 2002, 239, 19-38.

194. Chen, W.; Dunbabin, V.; Bell, R.; Brennan, R.; Bowden, B. Simulating and understanding root growth using rootmap to guide phosphorus fertiliser placement in wide row lupin cropping systems. In Proceedings of the 12th International Lupin Conference, Fremantle, Western Australia, 14-18 September 2008; pp. 368-372.

195. Dunbabin, V.M.; Diggle, A.J.; Rengel, Z. Simulation of field data by a basic three-dimensional model of interactive root growth. Plant Soil 2002, 239, 39-54.

196. McCown, R.L.; Hammer, G.L.; Hargreaves, J.N.G.; Holzworth, D.; Huth, N.I. Apsim-An agricultural production system simulation-model for operational-research. Math. Comput. Simul. 1995, 39, 225-231.

197. McCown, R.L.; Hammer, G.L.; Hargreaves, J.N.G.; Holzworth, D.P.; Freebairn, D.M. Apsim: A novel software system for model development, model testing and simulation in agricultural systems research. Agric. Syst. 1996, 50, 255-271.

198. Boote, K.J.; Jones, J.W.; White, J.W.; Asseng, S.; Lizaso, J.I. Putting mechanisms into crop production models. Plant Cell Environ. 2013, 36, 1658-1672. 
199. Dunbabin, V.M.; McDermott, S.; Bengough, A.G. Upscaling from rhizosphere to whole root system: Modelling the effects of phospholipid surfactants on water and nutrient uptake. Plant Soil 2006, 283, 57-72.

200. Dunbabin, V.M.; Airey, M.; Diggle, A.J.; Renton, M.; Rengel, Z.; Armstrong, R.; Chen, Y.; Siddique, K.H.M. Simulating the interaction between plant roots, soil water and nutrient flows, and barriers and objects in soil using rootmap. In Proceedings of the 19th International Congress on Modelling and Simulation (Modsim 2011), Perth, Western Australia, Australia, 12-16 December 2011; pp. 975-981.

201. Chen, Y.L.; Dunbabin, V.M.; Postma, J.A.; Diggle, A.J.; Siddique, K.H.M.; Rengel, Z. Modelling root plasticity and response of narrow-leafed lupin to heterogeneous phosphorus supply. Plant Soil 2013, 372, 319-337.

202. Stockle, C.O.; Martin, S.A.; Campbell, G.S. Cropsyst, a cropping systems simulations-model: Water/Nitrogen budgets and crop yield. Agric. Syst. 1994, 46, 335-359.

203. Anwar, M.R.; Liu, D.L.; Macadam, I.; Kelly, G. Adapting agriculture to climate change: A review. Theor. Appl. Climatol. 2013, 113, 225-245.

(C) 2014 by the authors; licensee MDPI, Basel, Switzerland. This article is an open access article distributed under the terms and conditions of the Creative Commons Attribution license (http://creativecommons.org/licenses/by/3.0/). 